Dr. sc. Dario Đerđa, izvanredni profesor

Pravnoga fakulteta u Rijeci

Dr. sc. Teodor Antić

glavni tajnik Ustavnog suda Republike Hrvatske

\title{
NADZOR NAD RADOM IZVRŠNIH I UPRAVNIH TIJELA JEDINICA LOKALNE SAMOUPRAVE U HRVATSKOJ
}

\author{
UDK: 352(497.5) \\ Izvorni znanstveni rad \\ Primljeno: 15. IX. 2015.
}

\begin{abstract}
Specifičnost nadzora nad radom izvršnih i upravnih tijela lokalne samouprave leži u opreci između upravnih obilježja jedinice lokalne samouprave i njezinih samoupravnih obilježja. Stoga on treba biti ustrojen na način kojim se respektiraju samoupravne ovlasti lokalne samouprave, ali pritom istodobno štiti zakonitost u cjelokupnom pravnom sustavu. U radu se istražuju oblici nadzora nad izvršnim i upravnim tijelima jedinica lokalne samouprave u Hrvatskoj, pri čemu se, nakon razmatranja prirode nadzora, subjekata nadzora $i$ nadzornih ovlasti, posebice analizira nadzor unutar samih tijela lokalne samouprave, hijerarhijski upravni nadzor od strane tijela područne (regionalne) samouprave te upravni i inspekcijski nadzor od strane Ministarstva uprave, upravnosudski nadzor kao i nadzor od strane pučkoga pravobranitelja. Poseban naglasak stavljen je na instrumente provođenja svakoga pojedinoga nadzora te na nadzorne ovlasti kojima raspolažu nadzorna tijela. Pritom se skreće pozornost na utjecaj koji na učinkovitost $i$ djelotvornost nadzora imaju broj $i$ veličina lokalnih jedinica i posljedično njihova objektivna sposobnost obavljanja poslova iz samoupravnog djelokruga.
\end{abstract}

Ključne riječi: nadzor nad javnom upravom, lokalna samouprava, nadzor nad lokalnim izvršnim i upravnim tijelima

\section{UVOD}

Sustavna i učinkovita vertikalna raspodjela funkcija u državi zadaća je svake odgovorne političke vlasti. Takva raspodjela funkcija osnova je kvalitetnog izvršavanja javnih poslova uopće. U tu svrhu, u svakoj državi ustrojavaju se različiti oblici teritorijalnih zajednica, od najviše tj. državne, preko područnih tj. regionalnih sve do osnovnih tj. lokalnih. U takvome uređenju sustav lokalne samouprave trebao bi pridonijeti što racionalnijem društvenom upravljanju u kojem građani lokalne zajednice u vlastitu interesu i na vlastitu odgovornost relativno samostalno uređuju obavljanje određenih javnih poslova i njima upravljaju, putem u državu integriranih pravnih osoba javnog prava, s tijelima koja su sami izabrali i pod nadzorom države. ${ }^{1}$ Lokalna samouprava čini dio šireg državnog sustava

1 Becker, Erich, Die Selbstverwaltung als verfassungsrechtliche Grundlage der kommunalen Ordnung in Bund und Ländern, Handbuch der kommunalen Wissenschaft und Praxis, Springer-Verlag, Berlin, Göttingen, Heidelberg, 1956., str. 121-122. 
Dr. sc. Dario Đerđa i dr. sc. Teodor Antić: Nadzor nad radom izvršnih i upravnih tijela jedinica... Zbornik radova Pravnog fakulteta u Splitu, god. 53, 1/2016., str. 165.-205.

koji je najbliži građanima i zbog toga je najprikladniji za uključivanje stanovnika lokalne zajednice u proces donošenja odluka od važnosti za tu zajednicu te za korištenje njihovih znanja i sposobnosti nužnih za njezin razvoj. Upravo stoga, jačanje lokalne samouprave pridonosi i jačanju područnih (regionalnih) zajednica te same države, slijedom čega mu se danas posvećuje posebna pozornost. ${ }^{2}$

U Republici Hrvatskoj jedinice lokalne samouprave i jedinice područne (regionalne) samouprave, njihov djelokrug i ustrojstvo, način rada njihovih tijela, nadzor nad njihovim aktima i radom te druga pitanja od značenja za njihov rad utvrđeni su Zakonom o lokalnoj i područnoj (regionalnoj) samoupravi. ${ }^{3}$ Jedinice lokalne samouprave su općine i gradovi, dok su jedinice područne (regionalne) samouprave županije. ${ }^{4}$ Općine, gradovi i županije osnivaju se isključivo zakonom. Općina je jedinica lokalne samouprave koja se osniva, u pravilu, za područje više naseljenih mjesta koja predstavljaju prirodnu, gospodarsku i društvenu cjelinu te koja su povezana zajedničkim interesima stanovništva. Grad je jedinica lokalne samouprave u kojoj je sjedište županije te svako mjesto koje ima više od 10.000 stanovnika, a predstavlja urbanu, povijesnu, prirodnu, gospodarsku i društvenu cjelinu. ${ }^{5}$ Veliki grad je jedinica lokalne samouprave koja je ujedno gospodarsko, financijsko, kulturno, zdravstveno, prometno i znanstveno središte razvitka šireg okruženja i koja ima više od 35.000 stanovnika. Iznimno, Grad Zagreb, kao glavni grad Republike Hrvatske, posebna je jedinstvena, teritorijalna i upravna cjelina kojoj je ustrojstvo uređeno posebnim zakonom - Zakonom o Gradu Zagrebu. ${ }^{6}$ Županija je jedinica područne (regionalne) samouprave čije područje predstavlja prirodnu, povijesnu, prometnu, gospodarsku, društvenu i samoupravnu cjelinu, a ustrojava se radi obavljanja poslova od područnoga (regionalnog) interesa. Stoga se županija ne može smatrati jedinicom lokalne samouprave. ${ }^{7}$ U Republici

2 Vidi i Svjetsku deklaraciju lokalne samouprave, World-wide Declaration of Local Self-government, Iula, 2003., dostupno na: www.bunken.nga.gr.jp/siryousitu/eturansitu/charter/iula_decl_txt.html., pristup: 5. lipnja 2015.

3 Zakon o lokalnoj i područnoj (regionalnoj) samoupravi, Narodne novine, br. 3/01., 60/01., 129/05., 109/07., 125/08., 36/09., 150/11. i 144/12.

4 Sustav lokalne samouprave ustrojen kroz dvije razine imaju brojne države članice Europske unije, među kojima su npr. Češka, Nizozemska i Švedska. Međutim, neke države u Uniji imaju samo jednu razinu ustroja lokalne samouprave, kao što je to slučaj u Bugarskoj, Cipru i Latviji, dok treće lokalnu samoupravu ustrojavaju kroz tri stupnja, kao što je to slučaj npr. u Francuskoj, Italiji i Poljskoj. Vidi Local self-government in the Member States of the European Union: a comparative legal perspective, National Institute of Public Administration, Spain, Madrid, 2012.

5 Iznimno, gdje za to postoje posebni razlozi, kao npr. povijesni, gospodarski, geoprometni, gradom se može utvrditi i mjesto koje ne zadovoljava navedene uvjete.

6 Grad Zagreb kao glavni grad Republike Hrvatske u sustavu lokalne samouprave ima poseban status. On je jedinica lokalne samouprave s položajem jedinice područne (regionalne) samouprave. Kao takvome, djelokrug i ustrojstvo uređuju mu se posebnim zakonom - Zakonom o Gradu Zagrebu, Narodne novine, br. 62/01., 125/08., 36/09. i 119/14. Odredbe Zakona o lokalnoj i područnoj (regionalnoj) samoupravi primjenjuju se na Grad Zagreb, samo ako tim Zakonom nije drukčije određeno.

Članci 1., 3. do 6. te 19.a Zakona o lokalnoj i područnoj (regionalnoj) samoupravi. Područje općine, grada i županije, njihov naziv, sjedište njihovih tijela, osnivanje novih te ukidanje ili spajanje postojećih općina, odnosno gradova, izdvajanje pojedinih naselja iz sastava jedne općine ili grada i uključivanje tih naselja u sastav druge općine ili grada, promjene granica kao i druga pitanja od važnosti za teritorijalne promjene jedinica lokalne i područne (regionalne) samouprave u Republici Hrvatskoj uređuju se Zakonom 
Dr. sc. Dario Đerđa i dr. sc. Teodor Antić: Nadzor nad radom izvršnih i upravnih tijela jedinica... Zbornik radova Pravnog fakulteta u Splitu, god. 53, 1/2016., str. 165.-205.

Hrvatskoj danas je ustrojeno 428 općina i 128 gradova, od čega je 17 velikih gradova, te 20 županija.

Jedinice lokalne samouprave u svom samoupravnom djelokrugu obavljaju poslove lokalnog značaja kojima se neposredno ostvaruju potrebe građana, a koji nisu Ustavom ili zakonom dodijeljeni državnim tijelima. Takvim poslovima izričito su propisani: uređenje naselja i stanovanje, prostorno i urbanističko planiranje, komunalno gospodarstvo, briga o djeci, socijalna skrb, primarna zdravstvena zaštita, odgoj i osnovno obrazovanje, kultura, tjelesna kultura i sport, zaštita potrošača, zaštita i unapređenje prirodnog okoliša, protupožarna i civilna zaštita, promet te ostali poslovi sukladno posebnim zakonima. Velikim gradovima djelokrug je proširen još za poslove koji se odnose na srednje i visoko obrazovanje, održavanje javnih cesta te izdavanje građevinskih i lokacijskih dozvola i drugih akata vezanih uz gradnju i provedbu dokumenata prostornog uređenja. Osim poslova iz samoupravnog djelokruga, jedinice lokalne samouprave mogu na svom području obavljati i poslove prenesenog odnosno povjerenog djelokruga, tj. poslove državne uprave određene zakonom. ${ }^{8}$

Navedenim ustrojem lokalne samouprave Republika Hrvatska se svrstava među države s malim jedinicama lokalne samouprave te među države s velikim brojem jedinica lokalne samouprave u odnosu na broj stanovnika. Međutim, takav trend velikoga broja jedinica lokalne samouprave, koje se u velikoj mjeri razlikuju svojom veličinom, brojem stanovnika, podmirivanjem javnih potreba svojega stanovništva, ali i stupnjem poduzetničke aktivnosti, dovodi do velikih problema u funkcioniranju nekih od njih. ${ }^{9} \mathrm{U}$ doktrinarnim analizama funkcioniranja lokalne

o područjima županija, gradova i općina u Republici Hrvatskoj, Narodne novine, br. 86/06., 125/06., 16/07., 95/08., 46/10., 145/10., 37/13., 44/13. i 45/13.

8 Članci 18. do 19.a Zakona o lokalnoj i područnoj (regionalnoj) samoupravi.

9 Povećanjem broja jedinica lokalne samouprave u Hrvatskoj smanjivala se njihova prosječna veličina u odnosu prema broju stanovnika. Osim toga, brojnim izmjenama zakona razmjerno velik broj općina stekao je status odnosno naziv grada mimo osnovnog mjerila - najmanje 10.000 stanovnika. Iz podataka popisa stanovništva vidljivo je da uz Grad Zagreb u kategoriju velikih gradova koji imaju preko 35.000 stanovnika ulazi još 16 gradova (13\%), dok gotovo polovina gradova (59 odnosno 46 $\%$ ) ima manje od 10.000 stanovnika. Također je vidljivo da više od polovine općina (275 odnosno 64 $\%$ ) ima manje od 3.000 stanovnika, a od toga 37 općina (8\%) ima manje od 1.000 stanovnika. Prema podacima Popisa stanovništva iz 2001. godine, prosječna jedinica lokalne samouprave te godine imala je 6.675 stanovnika (prosječna općina 3.214 stanovnika, prosječan grad 18.635 stanovnika). Kontingenti stanovništva po gradovima/općinama, popis 2001., Državni zavod za statistiku, dostupno na: www.dzs.hr/ Hrv/censuses/census2001/Popis/H01_01_02/H01_01_02.html, pristup: 21. svibnja 2015. Pri ovoj obradi podataka izostavljen je Grad Zagreb żbog nerazmjerno velikog broja stanovnika, tj. 779.145 stanovnika, u odnosu na druge jedinice lokalne samouprave, što bi iskrivilo sliku o prosječnoj veličini ovih jedinica. Prema posljednjem Popisu stanovništva iz 2011. godine, prosječna jedinica lokalne samouprave ima 6.286 stanovnika (prosječna općina 2.957 stanovnika, prosječan grad 17.668 stanovnika). Kontingenti stanovništva po gradovima/općinama, popis 2011., Državni zavod za statistiku, dostupno na: www.dzs.hr/ Hrv/censuses/census2011/results/htm/H01_01_03/H01_01_03 zup01.html, pristup: 13. svibnja 2015. Iz ove obrade podataka također je izostavljen Grad Zagreb iz prethodno navedenog razloga. Prosječan broj stanovnika jedinica lokalne samouprave u drugim državama Europske unije varira od preko 50.000, kao npr. u Danskoj i Litvi, do ispod 3.000 stanovnika, kao npr. u Cipru, Češkoj, Francuskoj, Luksemburgu i Slovačkoj. Na razini Europske unije jedinice lokalne samouprave u prosjeku imaju 15.647 stanovnika. Obrada podataka iz Local, op. cit. Pritom su u obradi, zbog neusporedivosti sustava, izostavljeni Irska, Portugal i Ujedinjeno Kraljevstvo. 
samouprave u Hrvatskoj ističe se niz negativnih čimbenika koji utječu na rad ovih jedinica. Ponajprije, teritorijalna struktura s općinama, gradovima i velikim gradovima, kao jedinicama lokalne samouprave, ali i županijama kao jedinicama područne (regionalne) samouprave, statističkim regijama te jedinicama $\mathrm{s}$ posebnim statusom, kao što su jedinice na područjima posebne državne skrbi, gradovi Vukovar i Zagreb te jedinice koje su preuzele decentralizirane funkcije, smatra se previše složenom te je u tom smislu potrebno uložiti velik napor u koordinaciju, usmjerivanje, povezivanje i obavljanje svakog značajnijeg posla. Zatim, nedovoljna stabilnost teritorijalne strukture, u kojoj je broj jedinica lokalne samouprave od 1991. do 2015. godine višestruko povećan bez unaprijed donesenog i promišljenog plana, ne otvara prostor za studiozno rješavanje pitanja broja, veličine, ali i kapaciteta ovih jedinica. Neuravnotežena struktura lokalnih jedinica, od kojih su neke vrlo male, a druge prilično velike, za posljedicu, između ostaloga, ima različitu ekonomsku snagu, slijedom čega neke mogu uložiti značajna sredstva u razvoj pa je u njima i položaj građana bolji. Sve ovo vodi nejednakosti uživanja usluga stanovnika različitih jedinica, ali i iseljavanju iz ekonomski slabo razvijenih dijelova Hrvatske prema onima koji su razvijeniji i imaju bolje razvojne mogućnosti. Na ovo se nadovezuju slabi razvojni potencijali koji su često posljedica slabog gospodarskog stanja i malog fiskalnog kapaciteta nekih jedinica lokalne samouprave, što vodi do značajnijeg razvoja tek manjeg dijela ovih jedinica. Konačno, jedan od najvažnijih problema lokalne samouprave svakako je njezina nedovoljna učinkovitost, praćena značajnim rastom broja zaposlenika u posljednjih 25 godina te izuzetno slabim financijskim kapacitetom za obavljanje vlastitih zadaća. Čak više od $40 \%$ jedinica lokalne samouprave može se ocijeniti financijski neodrživima, dok skoro jednak broj jedinica ovisi o financijskoj pomoći sa središnje državne razine. ${ }^{10}$ Slijedom navedenoga, određeni broj ovih jedinica svojim proračunskim sredstvima nije u mogućnosti financirati čak niti plaće svojih službenika, a koje poslovanje u pitanje dovodi prirodu njihovih samoupravnih ovlasti, posebno u kontekstu potpomognutoga financiranja sredstvima iz državnoga proračuna.

Upravo zbog niza negativnih čimbenika koji utječu na hrvatsku lokalnu samoupravu, te nerijetko, nedovoljne kapacitiranosti nekih jedinica lokalne samouprave da se učinkovito nose sa zadaćama koje su im zakonom povjerene, posebnu pozornost treba staviti na zakonitost i pravilnost rada izvršnih i upravnih tijela ovih jedinica. U izvršna tijela jedinica lokalne samouprave ubrajaju se općinski načelnik i gradonačelnik, a u upravna tijela upravni odjeli i službe. Međutim, neke izvršne i upravne ovlasti u pojedinim slučajevima mogu biti zakonom podijeljene i predstavničkom tijelu jedinice lokalne samouprave. Izniman značaj izvršnih i upravnih poslova koje obavljaju izvršna i upravna tijela jedinica lokalne samouprave posebno se ogleda pri rješavanju u upravnim stvarima o pravima i obvezama pojedinaca - građana i pravnih osoba, ali i poduzimanju drugih upravnih radnji koje imaju učinak na prava i pravne interese ovih osoba.

10 O ovome više vidi u Koprić, Ivan, „Karakteristike sustava lokalne samouprave u Hrvatskoj“, Hrvatska javna uprava, god. 10., br. 2., 2010., str. 371-386. 
Stoga se, u velikom, prilično usitnjenom i nedostatno kapacitiranom sustavu, kao izuzetno bitno čini pitanje nadzora nad radom tijela koja koriste javne ovlasti. U ovome radu detaljnije će se istražiti oblici nadzora nad izvršnim i upravnim tijelima jedinica lokalne samouprave u Hrvatskoj, pri čemu se, nakon razmatranja prirode nadzora, subjekata nadzora i nadzornih ovlasti, analiziraju specifičnosti nadzora unutar samih tijela lokalne samouprave, upravnog nadzora nad radom ovih tijela, nadzor nad ovim tijelima koji provode sudovi te nadzor od pučkoga pravobranitelja. U radu se poseban naglasak stavlja na instrumente provođenja svakoga pojedinoga nadzora te nadzorne ovlasti kojima raspolažu nadzorna tijela.

\section{OSNOVNA PITANJA NADZORA NAD IZVRŠNIM I UPRAVNIM TIJELIMA JEDINICA LOKALNE SAMOUPRAVE}

Velik broj jedinica lokalne samouprave u Republici Hrvatskoj te brojne ovlasti koje su im prenesene, povlači izuzetno ozbiljan, ne samo pravni već i politički problem - zakonitost i pravilnost obavljanja poslova kojima ove jedinice provode javne ovlasti povjerene im zakonom. Stoga se kao posebno važno pitanje, koje u velikoj mjeri utječe na ostvarivanje prava pojedinaca, ali i na zaštitu njihovih pravnih interesa, postavlja pitanje pravnih instrumenata koje je razvilo suvremeno hrvatsko pravo, a s ciljem osiguravanja zakonitog i pravilnog djelovanja jedinica lokalne samouprave. Time se u prvi plan stavljaju mehanizmi pravnoga nadzora nad ovim, za svakodnevni život građana izuzetno važnim čimbenicima javnoga sektora uopće.

Nadzor se posebno važnim pokazuje upravo u funkcioniranju tijela koja obavljaju izvršne i upravne poslove u državi. Kao razlog tome u pravnoj doktrini ističu se brojne specifičnosti ustroja i funkcioniranja ovih tijela. Primjerice, piramidalni ustroj izvršne vlasti nužno rezultira međusobnim odnosom nadređenosti i podređenosti. Također, zbog prirode poslova koje obavljaju tijela izvršne vlasti ona su, čak i u najdemokratskijim društvima, manje sklona kompromisu, a više afirmaciji vlastitog gledišta kao dominantnog. Radi svoje ustavne funkcije javljaju se kao inicijator i nositelj javnih politika, cjelovite predodžbe o svakodobnom prioritetu problema pred društvom i načinu njihova rješavanja, pri čemu se u pravilu vode racionalnim izborom između alternativa koje im stoje na raspolaganju. Stavovi službenika zaposlenih u upravnim tijelima često su oblikovani u prvom redu ulogom i normativnim zahtjevima postavljenim pred ustrojstvenom jedinicom u kojoj rade. ${ }^{11}$ Sve ovo ukazuje kako su tijela koja obavljaju izvršne poslove u mogućnosti inicirati donošenje pravnih propisa koji pogoduju ostvarivanju njihovih interesa te tumačiti i provoditi takve propise na način koji nije pravno utemeljen, a što za posljedicu ima povredu prava i pravnih interesa pojedinaca, kako građana tako i poduzetnika, na državnoj, područnoj (regionalnoj) ili lokalnoj razini. Upravo stoga, nadzor zakonitosti i pravilnosti postupanja izvršnih tijela jedinica lokalne samouprave postaje izuzetno važno pravno pitanje.

11 Pusić, Eugen, „Kontrola vlasti pomoću vlasti“, Politička misao, vol. 31., br. 3., 1994., str. 28. 
Dr. sc. Dario Đerđa i dr. sc. Teodor Antić: Nadzor nad radom izvršnih i upravnih tijela jedinica... Zbornik radova Pravnog fakulteta u Splitu, god. 53, 1/2016., str. 165.-205.

Međutim, pitanju nadzora nad tijelima koja obavljaju izvršne poslove, u prvome redu javnom upravom, u znanstvenoj i stručnoj literaturi nije posvećeno mnogo pozornosti. Ona posebno nije posvećena nadzoru nad radom izvršnih tijela u jedinicama lokalne i područne samouprave. Iako se značaj nadzora u javnoj upravi odavno ističe, ne pridaje mu se zaslužena pozornost. ${ }^{12} \mathrm{U}$ svezi s njime, u pravilu se ističe nužnost nadzora nad upravom te se upozorava kako nadzor predstavlja sastavni dio upravljanja uopće, tj. obvezni posljednji segment upravljanja. Razlog je tome što se upravljanje ne može ocijeniti cjelovitim bez usporedbe stvarne djelatnosti javnopravnih tijela, $\mathrm{tj}$. rezultata njihove djelatnosti $\mathrm{s}$ djelatnošću i rezultatima koji se očekuju na osnovi unaprijed utvrđenih kriterija. ${ }^{13}$ Time nadzor čini stadij upravljanja u kojemu se valoriziraju poduzete radnje te utvrđuje njihova zakonitost i pravilnost, a čime nadilazi jednostavno evidentiranje pogrešaka u radu javnopravnih tijela. Dobro ustrojen nadzor nema zadaću samo ukloniti nezakonitost ili nepravilnost iz pravnoga sustava, već bi trebao pružiti pomoć nadziranome javnopravnom tijelu, a kako bi se u budućnosti izbjegle pogreške u njegovu radu, kao i unaprijediti rad tijela, ponajprije osposobljavanjem i usavršavanjem njegovih zaposlenika. Time nadzor predstavlja složenu aktivnost koja još ukazuje i je li određeno javnopravno tijelo dobro ustrojeno, postupa li ono pravilno te je li kadrovski kvalitetno ekipirano. Konačno, provedbom nadzora testiraju se i sami opći akti koje nadzirano tijelo u radu primjenjuje, gdje se iz nepravednih odluka koje su rezultat ispravnoga tumačenja opće pravne norme zaključuje o njezinome lošem i pogrešnom nomotehničkom oblikovanju. ${ }^{14}$ Slijedom navedenoga, može se zaključiti kako se nadzor nad upravom obavlja s ciljem poboljšanja njezine kvalitete i uspješnosti rada, ne samo u pojedinačnim slučajevima, već uopće. ${ }^{15}$

Međutim, unatoč tome što se u nekim, ponajprije udžbeničkim djelima iz upravnoga prava i upravne znanosti kao i u znanstvenim i stručnim člancima analiziraju temeljna pitanja nadzora nad izvršnim i upravnim tijelima te se prikazuju neki tehnički postupci koji se prilikom provedbe nadzora moraju slijediti odnosno pristupa se analizi nekih specifičnih oblika nadzora, ${ }^{16}$ ne može se ustvrditi kako

12 Aviani naglašava kako je problem djelotvorne nadzorne aktivnosti uprave nesumnjivo jedan od glavnih političkih, organizacijskih i društvenih problema našeg vremena, dok je Pusić još prije 20 godina istaknuo kako je u svakoj zajednici, s ciljem njezina opstanka, neophodno postaviti čuvare reda u njoj. Pri tome je ujedno postavio i suštinsko pitanje u svrhu utvrđivanja nadzora, no na koje nije dao odgovor - quis custodiat custodes. Vidi Aviani, Damir, Parlamentarni ombudsman, Pravni fakultet u Splitu, Split, 1999. str. 25. te Pusić, Eugen, „Tko da čuva čuvare“, Erasmus, br. 10., 1995., str. 12.

13 Pusić, Eugen, Nauka o upravi, Školska knjiga, Zagreb, 2002., str. 346. Slično, Borković kontrolu nad upravom određuje kao kontinuiranu djelatnost nadzora što ga pravno ovlašteni subjekti provode nad ponašanjem uprave, načinom upotrebe njezinih ovlasti i aktima odnosno mjerama što proizlaze iz upotrebe ovih ovlasti. Borković, Ivo, Upravno pravo, Narodne novine, Zagreb, 2002., str. 112.

14 Krbek, Ivo, Pravo jugoslavenske javne uprave: Osnovna pitanja i prava građana, knj. 1., Birotehnički izdavački zavod, Zagreb, 1960., str. 79. No, važno je naglasiti kako nadzor nužno ne implicira i utvrđivanje krivnje i odgovornosti službenika koji je poduzeo nezakonitu ili nepravilnu radnju.

15 Vidi Blažević, Robert, Upravna znanost, Pravni fakultet u Rijeci, Rijeka, 2015., str. 136.

16 Vidi npr. Krišković, Velimir, „Viši nadzor nad upravom“, str. 175-186., Ivančević, Velimir, „Pravna zaštita građana kod šutnje administracije“, str. 187-216., Medvedović, Dragan, „Kakva pravna zaštita 
Dr. sc. Dario Đerđa i dr. sc. Teodor Antić: Nadzor nad radom izvršnih i upravnih tijela jedinica... Zbornik radova Pravnog fakulteta u Splitu, god. 53, 1/2016., str. 165.-205.

se problematici nadzora nad javnom upravom u Hrvatskoj pristupilo sustavno i studiozno. ${ }^{17}$

Kada se razmatra nadzor nad javnom upravom u pravnoj doktrini, ovisno o pravnoj prirodi razlikuju se četiri temeljne vrste nadzora: tehnički, politički, društveni i pravni nadzor. Značajka je tehničkoga nadzora uspoređivanje određene aktivnosti javnopravnoga tijela s odgovarajućim proračunima ili drugim tehničkim uputama koje tijelo mora slijediti. Politički nadzor odnosi se na ocjenu je li neka radnja poduzeta u skladu s političkom odlukom, stavovima, načelnim opredjeljenjima i sl. Društveni nadzor prvenstveno vodi računa o standardima javnosti rada, pravednosti, morala, razumnosti i sl., a u skladu s prilikama danoga vremena i mjesta. Konačno, pravni nadzor, koji je i predmet ovoga rada, utvrđuje je li postupanje nekoga tijela sukladno pravnim mjerilima izraženim kroz donesena pravna pravila. Stoga ovaj nadzor uvijek treba biti unaprijed utvrđen i uređen pravnim pravilima, treba se zasnivati na poštovanju pravnih mjerila i standarda, a tijelo koje ga obavlja treba imati pravne ovlasti u odnosu na nadzirano tijelo u svezi s predmetom nadzora. ${ }^{18}$

No, kako bi pravni nadzor nad radom tijela koja obavljaju izvršne i upravne poslove polučio sve ove rezultate, on u prvome redu treba biti konstantan, tj. obavljati se kao trajna djelatnost, i višestruk, tj. osigurati mehanizme koji mogu odgovoriti

građana od nezakonitih i nepravilnih upravnih akata lokalnih organa“, str. 217-228., Borković, Ivo, „Kontrola uprave putem redovitih sudova“, str. 279-292., sve u: Hrestomatija upravnog prava, Društveno veleučilište u Zagrebu, Pravni fakultet u Zagrebu, Zagreb, 2003.; vidi također: Krbek, Ivo, Osnovi upravnog prava FNRJ, Jugoslavenska akademija znanosti i umjetnosti, Zagreb, 1950., str. 563-591., Krbek, Pravo..., op. cit., str. 79-83., Borković, Upravno..., op. cit., str. 112-130., Pusić, Nauka..., op. cit., str. 346-356.

17 Nadzoru nad lokalnom samoupravom posvećen je nevelik broj radova kao npr. Krbek, Ivo, „Državni nadzor nad samoupravom“, Mjesečnik: Glasilo pravničkog društva, god. 65., br. 7-8. 1939., Antić, Teodor, „Nadzor lokalne samouprave - postojeće stanje i prijedlog promjena“, Reforma lokalne i regionalne samouprave u Republici Hrvatskoj, Institut za javnu upravu, Pravni fakultet Sveučilišta u Zagrebu, Zagreb, 2013., str. 219-249., Antić, Teodor, „Nadzor i pravna zaštita lokalne samouprave de lege lata $\mathrm{i}$ de lege ferenda“, Nova hrvatska lokalna i regionalna samouprava, Hrvatska akademija znanosti i umjetnosti, Zagreb, 2010., str 363-407., Gagro, Božidar, „Upravnosudski nadzor zakonitosti akata jedinica lokalne i područne (regionalne) samouprave“, Hrvatska javna uprava, god. 3., br. 3-4., 2001., str. 543-557, Kasabašić, Štefanija, „Državni nadzor i zaštita lokalne i područne (regionalne) samouprave“, Informator, god. 54., br. 5435., 2006., str. 6-7., Koprić, Ivan, „Proširenje lokalnog samoupravnog djelokruga i sužavanje nadzora središnjih državnih organa“, Hrvatska javna uprava, god. 2., br. 3, 2000., str. 391-436., Medvedović, Dragan, „Kontrola ustavnosti i zakonitosti općih akata općina i gradova“, Hrvatska javna uprava, god. 3., br. 3-4., 2001., str. 495-542., Medvedović, Dragan, „Nadzor izvršne vlasti nad općim aktima jedinica lokalne samouprave - de lege lata i de lege ferenda“, Hrvatska javna uprava, god. 5., br. 1., 2005., str. 81-110., Šprajc, Ivan, „Nadzor nad djelovanjem tijela jedinica lokalne samouprave: međunarodnopravne osnove i pregled usporednog prava“, Hrvatska javna uprava, god. 2., br. 3., 2000., str. 525-560., Tropina-Godec, Zeljka, ,Još o nadzoru općih akata i zakonitosti rada predstavničkih tijela jedinica lokalne i područne (regionalne) samouprave“", Informator, god. 54., br. 5439, 2006., str. 16-18. i sl.

18 Tomić, Zoran R., Opšte upravno pravo, Pravni fakultet u Beogradu, Beograd, 2009., str. 53-54. Tehnički, politički i društveni nadzor Tomić još naziva i izvanpravnim nadzorima, jer oni bazično polaze od političkih, stručno-tehničkih i širih društvenih vrijednosti, a u prvom planu nemaju pravnu normu kao kontrolni uzor. Međutim, naglašava kako, unatoč drukčijoj polaznoj osnovi, ovi oblici nadzora pravnu normu ipak ne smiju ignorirati. 
različitim izazovima koji se javljaju u obavljanju izvršne i upravne djelatnosti. ${ }^{19}$ On mora biti usmjeren na ustrojstvene, postupovne i kadrovske segmente uprave. ${ }^{20}$ Kao pokazatelji kvalitete nadzora posebno se ističu: pravodobnost nadzora, tj. provedba nadzora prije nastupa štetnih posljedica; ekonomičnost nadzora, tj. vođenje računa da troškovi nadzora ne prijeđu njegovu korist; obuhvat nadzora, tj. uzimanje u obzir što više relevantnih elemenata nadzirane djelatnosti; te uravnoteženost nadzora, tj. da nadzor posredno ne uzrokuje zapuštanje drugih djelatnosti ili zadataka javnopravnog tijela koncentrirajući pozornost samo na neke od njih. ${ }^{21}$

Nadzor nad tijelima koja obavljaju izvršne i upravne poslove vrlo je važan jer, pored represivnoga, ima i preventivni učinak. Represivni učinak nadzora nad upravom očituje se u tome što nositelji nadzora, kad utvrde nezakonitost odnosno nepravilnost u djelovanju javnopravnoga tijela nad kojim provode nadzor, poduzimaju učinkovite radnje iz kruga nadzornih ovlasti i time otklanjaju mogućnost da na snazi ostanu odluke ili mjere kojima je povrijeđeno načelo zakonitosti odnosno svrhovitosti. Preventivni učinak nadzora nad ovim tijelima ogleda se u činjenici da sama izvršna i upravna tijela, znajući da njihove radnje, akte i mjere nadzire uspostavljeno nadzorno tijelo, unaprijed paze na zakonitost i svrhovitost svojih odluka i radnji, svjesna okolnosti da će eventualne pogreške u radu izazvati reakciju nositelja nadzora što će, opet, rezultirati poduzimanjem nadzornih ovlasti sa svim posljedicama koje iz toga za upravu mogu proizići. ${ }^{22}$ Djelotvornost nadzora nad upravom ovisi o dva važna čimbenika: veličini broja subjekata koji su ovlašteni provoditi ovaj nadzor i širini nadzornih ovlasti kojima ovi subjekti u provođenju nadzora raspolažu. Što je veći broj nositelja nadzora i što su njihove nadzorne ovlasti šire, to je i nadzor djelotvorniji i obrnuto. ${ }^{23}$

Kada se razmatra nadzor na izvršnim i upravnim tijelima uopće, pa tako i izvršnim i upravnim tijelima jedinica lokalne samouprave, u prvom su planu dva oblika nadzora: nadzor zakonitosti i nadzor pravilnosti, tj. svrhovitosti. Nadzor zakonitosti oblik je nadzora kojim se uspoređuje suglasnost odluka i radnji javnopravnoga tijela s pravnim pravilima koja reguliraju kada je takve odluke dopušteno donijeti odnosno radnje poduzeti, postupak njihova donošenja odnosno

19 Vidi Borković, Upravno..., op. cit., str. 112. Borković naglašava da je u svim državama, bez obzira na njihovo društveno i političko uređenje, posvećena posebna briga ustroju i položaju upravnih tijela, širini njihovih ovlasti i načinu na koji ona te ovlasti ostvaruju i primjenjuju.

20 Vidi Krbek, Pravo..., op. cit., str. 79. Krbek ističe kako nadzor treba obuhvatiti i materijalni i personalni aspekt obavljanja nadzorne djelatnosti, kako ne smije biti ustrojen samo usko formalno i birokratski, već treba biti stvaran i djelotvoran te kako se ne smije svoditi samo na neke specifične odnosno izabrane slučajeve, već treba biti postojan i sustavan.

21 Pusić, Nauka..., op. cit., str. 350. Pusić ukazuje kako vremenom cilj i način provedbe nadzora evaluira te se mijenjanjem odnosa u upravi mijenja i sadržaj funkcije nadzora. On se od primjene vlasti u sklopu unutarnjih odnosa u javnopravnim tijelima sve više pretvara u stručnu djelatnost određivanja kriterija uspješnosti, mjerenja odstupanja od tih kriterija i ispravljanja ovih odstupanja, čime on od nadzora nad radom službenika prerasta u nadzor nad objektivnim tijekovima i procesima.

22 Borković, Upravno..., op. cit., str. 114.

23 Loc. cit. te Tomić, op. cit., str. 54. 
poduzimanja te usklađenost odluka i mjera s materijalnim propisima. Time ovaj nadzor strogo vodi računa o pravnim segmentima nadziranih odluka i postupanja. Usmjeren je na provjeru je li izvršnom odnosno upravnom radnjom povrijeđen mjerodavni postupovni i materijalni zakon, drugi propis ili opći akt. Nadzor pravilnosti jest oblik nadzora kod kojega se odluke i radnje izvršnih i upravnih tijela uspoređuju s ciljem koji je trebalo postići. Cilj ovoga nadzora je ispitati pravilnosti slobodnoga odlučivanja. Tom se prilikom nadzire jesu li izvršna i upravna tijela, rješavajući po zakonski postavljenom ovlaštenju u određenim životnim situacijama, izabrala - s obzirom na sve konkretne okolnosti - najbolju od alternativa ponuđenih pravnom normom. ${ }^{24}$

U obavljanju nadzora nad izvršnim i upravim tijelima posebno treba razlikovati subjekte nadzora, predmet nadzora i nadzorne ovlasti. Subjekti nadzora su nositelji nadzora i tijela nad kojima se nadzor provodi. Nositelji nadzora subjekti su koji su pravnom normom ovlašteni obavljati određeni oblik nadzora nad izvršnim i upravnim tijelima te u određenim slučajevima koristiti nadzorne ovlasti kojima raspolažu. U hrvatskoj pravnoj doktrini ovdje se posebno ističe nadzor putem predstavničkoga tijela, nadzor pučkog pravobranitelja, nadzor unutar uprave, nadzor društvene zajednice, nadzor državnoga odvjetnika i drugih posebnih tijela, sudski nadzor i sl. ${ }^{25}$ Tijela nad kojima se nadzor obavlja različita su javnopravna tijela, tj. tijela državne uprave i druga državna tijela, tijela jedinica lokalne i područne (regionalne) samouprave, pravne osobe koje imaju javne ovlasti i pravne osobe koje obavljaju javnu službu. ${ }^{26}$ Tijela nad kojima se obavlja nadzor imaju obvezu ne samo trpjeti nadzor, tj. ne sprečavati ga, već pri obavljanju nadzora trebaju surađivati s nositeljem nadzora.

Predmet nadzora predstavljaju sve radnje izvršnih i upravnih tijela, dakle radnje izvršavanja zakona, propisa i općih akata, donošenja propisa i općih akata te obavljanje drugih upravnih i stručnih poslova. Nadzorne ovlasti čine skup svih mjera koje nositelj nadzora može upotrijebiti kad utvrdi da tijelo nad kojim se nadzor obavlja ne postupa onako kako je u danoj situaciji propisano odnosno svrhovito. Prema širini nadzornih ovlasti, one se svrstavaju u ovlast konstatacije, ovlast objektivnog stavljanja izvan snage i ovlast meritornoga rješavanja. Konstatacija je najblaži oblik nadzornih ovlasti kojom nositelj nadzora ima mogućnost jedino utvrditi da je u djelovanju tijela nad kojim nadzor provodi bilo izvjesnih nezakonitosti odnosno nepravilnosti. U takvoj situaciji nositelj nadzora je obično dužan upozoriti druge subjekte koji raspolažu represivnim mjerama da bi uočene

24 Borković, Upravno..., op. cit., str. 112-113. Pored ove podjele nadzora nad izvršnim i upravim poslovima, u pravnoj doktrini susreće se niz različitih podjela koje se vezuju uz obavljanje nadzorne djelatnosti kao npr. nadzor rezultata rada i nadzor načina rada; nadzor sadržaja i nadzor ekonomičnosti; opći nadzor i specifičan nadzor; unutarnji nadzor i vanjski nadzor; prethodni nadzor i naknadni nadzor; nadzor akata i nadzor postupanja; nadzor koji se obavlja po službenoj dužnosti i nadzor koji se obavlja na prijedlog stranke i sl. Više o ovome vidi u Pusić, Nauka..., op. cit., str. 346-347. i Krbek, Pravo..., op. cit., str. 81-82.

25 Borković, Upravno..., op. cit., str. 113-130.

26 Vidi članak 1. Zakona o općem upravnom postupku, Narodne novine, br. 47/09. i članak 2., stavak 2. Zakona o upravnim sporovima, Narodne novine, br. 20/10., 143/12. i 152/14. 
nezakonitosti odnosno nepravilnosti bile eliminirane iz pravnoga sustava. Kod objektivnog stavljanja izvan snage nositelj nadzora, nakon uočene nezakonitosti odnosno nepravilnosti u radu tijela nad kojim provodi nadzor, ima ovlast izravno intervenirati prema nezakonitim ili nepravilnim odlukama, stavljajući ih izvan snage s učinkom poništavanja ili ukidanja. Meritorno rješavanje podrazumijeva najšire ovlasti na strani nositelja nadzora, koje mu daju pravo, nakon što je utvrdio nezakonitost odnosno nepravilnost takve odluke i prema njoj primijenio mjeru objektivnog stavljanja izvan snage, svojom odlukom zamijeniti odluku tijela nad kojim je proveo nadzor. ${ }^{27}$

Specifičnost je svih javnopravnih tijela nad kojima se provodi nadzor vrlo stroga pravna uređenost njihova ustroja i funkcioniranja, tj. ustrojstvenog oblika ovih tijela, pravne osobnosti, uvjeta i načina zapošljavanja djelatnika u njima, pravnih osnova i načina poduzimanja radnji i donošenja pravnih odluka, financijskog poslovanja, odgovornosti zaposlenika za povrede obveza iz radnoga odnosa i sl. Zbog takve opsežne i detaljne pravne regulacije, nadzor nad ovim tijelima olakšan je, jer je malo pitanja, koja se odnose na djelovanje ovih tijela, izmaklo normiranju zakonodavca pa se pitanja koja se u praksi otvaraju više čine posljedicom nomotehničkih slabosti u formuliranju pravnih pravila negoli njihovog izostanka. Kada se promatraju jedinice lokalne samouprave značajnija odstupanja od navedenoga ne uočavaju se. Lokalna samouprava uređena je sistemskim zakonima: Zakonom o lokalnoj i područnoj (regionalnoj) samoupravi, Zakonom o financiranju jedinica lokalne i područne (regionalne) samouprave, Zakonom o lokalnim izborima i Zakonom o službenicima i namještenicima u lokalnoj i područnoj (regionalnoj) samoupravi. ${ }^{28}$ Međutim, pored ovih zakona, brojni aspekti djelovanja lokalne samouprave uređeni su i mnogim drugim materijalnim i postupovnim propisima, kao npr. Zakonom o općem upravnom postupku, Zakonom o komunalnom gospodarstvu, Zakonom o predškolskom odgoju i obrazovanju, Zakonom o socijalnoj skrbi, Zakonom o vatrogastvu i sl. ${ }^{29}$

Nadzor nad izvršnim i upravnim tijelima jedinica lokalne samouprave posebno složenim čini postojanje dvije različite razine vlasti na istom području - središnje državne vlasti i lokalne samouprave, kao i određeni stupanj autonomije, tj. slobode i samostalnosti lokalne samouprave i njezina utjecaja na opći interes te na pojedinačne interese u zajednici. Ova temeljna načela lokalne samouprave općenito nameću potrebu uspostave odgovarajućeg sustava nadzora nad njezinim

27 Borković, Upravno..., op. cit., str. 113. Ista sistematizacija nadzornih ovlasti susreće se i kod Krbeka u Krbek, Pravo..., op. cit., str. 82.

28 Zakon o financiranju jedinica lokalne i područne (regionalne) samouprave, Narodne novine, br. 117/93., 92/94., 69/97., 33/00., 73/00., 127/00., 59/01., 107/01., 117/01., 150/02., 147/03., 132/06., 26/07., 73/08., 25/12. i 147/14., Zakon o lokalnim izborima, Narodne novine, br. 144/12. i Zakon o službenicima i namještenicima u lokalnoj i područnoj (regionalnoj) samoupravi, Narodne novine, br. 86/08. i 61/11.

29 Zakon o komunalnom gospodarstvu, Narodne novine, br. 36/95., 36/95., 70/97., 128/99., 57/00., 129/00., 59/01., 82/04., 178/04., 38/09., 79/09., 153/09., 49/11., 84/11., 90/11., 144/12., 94/13., 153/13., 147/14. i 36/15., Zakon o predškolskom odgoju i obrazovanju, Narodne novine, br. 10/97., 107/07. i 94/13., Zakon o socijalnoj skrbi, Narodne novine, br. 157/13. i 152/14. i Zakon o vatrogastvu, Narodne novine, br. 106/99., 117/01., 36/02., 96/03., 174/04., 38/09. i 80/10. 
radom. Specifičnost tog nadzora posebno se zasniva na opreci između upravnih obilježja jedinice lokalne samouprave, koji je čine pravnom osobom javnog prava, i njezinih samoupravnih obilježja, koja je u odnosnu na državu čine pravnom osobom privatnog prava. Međutim, unatoč svojim oprečnim funkcijama, lokalna samouprava ne može izmaći državnom nadzoru. ${ }^{30}$ Stoga se, pored nadzora unutar tijela jedinica lokalne samouprave, a koji predstavlja nadzor izvan utjecaja države i njezinih tijela, nad lokalnom samoupravom provode i drugi oblici nadzora propisani zakonom, a koje u pravilu provode od države osnovana tijela. Tako se posebno važnim za zakonit rad tijela jedinica lokalne samouprave smatra nadzor koji nad lokalnom samoupravom obavljaju tijela jedinice područne (regionalne) samouprave i državna upravna tijela, nadzor koji nad lokalnom samoupravom obavljaju sudovi te nadzor koji nad lokalnom samoupravom obavlja pučki pravobranitelj. U radu se dalje analizira svaki od ovih oblika nadzora usmjeren na rad izvršnih i upravnih tijela jedinica lokalne samouprave, utvrđujući tijela nadležna za provedbu ovoga nadzora, inicijativu za njegovo pokretanje, postupak provedbe te učinak koji takav nadzor ima na utvrđenu nezakonitost ili nepravilnost.

\section{NADZOR UNUTAR UPRAVNIH TIJELA JEDINICE LOKALNE SAMOUPRAVE}

Osnovni nadzor zakonitosti i pravilnosti rada svakog javnopravnoga tijela osigurava se već u okviru samoga tijela. Smatra se kako ne postoji razlog za uključivanje u postupak nadzora drugih, tj. vanjskih tijela, kojima je obavljanje nadzora isključivi ili samo jedan od poslova sve dok se nezakonitost i nepravilnost učinkovito može ukloniti unutar samoga tijela koje je takvu odluku donijelo ili radnju poduzelo. Često do poduzimanja nezakonite ili nepravilne radnje dolazi iz neznanja ili nehata službenika koji tu radnju poduzima, te koji će, ukoliko ga se upozori na njezinu nezakonitost ili nepravilnost, takvu radnju ispraviti i provesti sukladno zakonu. U tom slučaju, svaki daljnji nadzor postaje nepotreban. Mogućnošću korekcije nezakonitosti i nepravilnosti od samoga tijela koje ju je i prouzročilo, uvelike se doprinosi učinkovitosti i ekonomičnosti sustava javne uprave uopće. Stoga su u pravnome nadzoru razvijeni mehanizmi koji takav nadzor potiču te koje mogu inicirati i osobe kojima su prava i pravni interesi takvom odlukom ili postupanjem povrijeđeni, ali i sama javnopravna tijela koja te radnje poduzimaju, a temeljem sustavnog i kontinuiranog vođenja računa o postupanju tijela u okviru njega samoga. Takvi mehanizmi ne samo da imaju cilj

30 S obzirom na opisanu složenost odnosa države i lokalne samouprave, Europskom poveljom o lokalnoj samoupravi kao osnovna načela i standardi nadzora propisani su načelo zakonitosti, prema kojem se upravni nadzor nad lokalnim jedinicama od strane vlasti višeg stupnja može obavljati samo u slučajevima i u oblicima predviđenim ustavom i zakonom te u pravilu ima svrhu osigurati poštovanje načela zakonitosti i ustavnosti, a jedino u slučaju kad je riječ o obavljanju prenesene ovlasti on može obuhvatiti i svrsishodnost, i načelo razmjernosti, prema kojem se nadzor mora obavljati tako da se poštuje razmjernost između širine intervencije nadzorne vlasti i važnosti interesa koje se namjerava štititi. Vidi članak 8. Europske povelje o lokalnoj samoupravi. Zakon o potvrđivanju Europske povelje o lokalnoj samoupravi, Narodne novine - međunarodni ugovori, broj 14/97., 2/07., 4/08. i 5/08. 
Dr. sc. Dario Đerđa i dr. sc. Teodor Antić: Nadzor nad radom izvršnih i upravnih tijela jedinica... Zbornik radova Pravnog fakulteta u Splitu, god. 53, 1/2016., str. 165.-205.

ispraviti nezakonito ili nepravilno postupanje, već bi trebali spriječiti njihovo ponavljanje u budućnosti.

Osnovni mehanizam koji omogućuju ponovno propitivanje zakonitosti poduzete radnje izvršnog ili upravnog tijela jedinice lokalne samouprave, a koji može inicirati sama osoba koja drži da su joj prava i pravni interesi povrijeđeni postupanjem takvoga tijela jest nadzor koji se pokreće prigovorom - redovitim pravnim lijekom propisanim općim upravnopostupovnim zakonom, tj. Zakonom o općem upravnom postupku. ${ }^{31}$ Sukladno europskim standardima javne uprave, a u skladu s načelom vladavine prava kao temeljnim načelom svake pravne države, Zakon o općem upravnom postupku nije se zadržao samo na osiguravanju pravne zaštite stranaka u slučajevima kada javnopravna tijela donose rješenja, već je, pored žalbe kao redovitog pravnog lijeka u upravnom postupku, u opće upravnopostupovno pravo uveo i pravni lijek koji bi trebao zaštititi građane od postupanja javne uprave koja se ne svode na donošenje i izvršavanje rješenja. Upravo prigovorom upotpunjena je zaštita od sveobuhvatnog upravnog djelovanja javnopravnih tijela u Republici Hrvatskoj.

Prigovorom, dakle, neka osoba ima mogućnost zaštititi svoja prava u brojnim slučajevima postupanja javnopravnog tijela u kojima se ne donosi rješenje. ${ }^{32}$ Kako je prema osnovnoj koncepciji Zakona o općem upravnom postupku prigovor remonstrativni pravni lijek, prigovor protiv navodnih nezakonitih postupanja javnopravnih tijela, pa tako i upravnih tijela jedinica lokalne samouprave, izjavljuje se čelniku toga tijela. Time se, postupajući po prigovoru, nadzor obavlja u okviru istoga tijela na čije je on postupanje izjavljen, a što ga u pravnoj doktrini i razlikuje od žalbe. O prigovoru odlučuje čelnik tijela rješenjem, u roku od osam dana od dana izjavljivanja prigovora. ${ }^{33}$ Međutim, kako bi pravna zaštita bila potpuna, te kako bi se zakonitost i pravilnost odluke po prigovoru mogla ispitati i drugim nadzornim mehanizmima, protiv rješenja prvostupanjskog tijela o prigovoru može se izjaviti žalba, a protiv rješenja drugostupanjskog tijela o prigovoru može se pokrenuti upravni spor. ${ }^{34}$ Zanimljivo je naglasiti kako se ovim zakonskom rješenjem otvara mogućnost da se o određenoj stvari o kojoj se nije vodio upravni postupak, takav postupak mora provesti, jer je rješenje koje se donosi u postupku po prigovoru upravni akt. ${ }^{35}$

31 Prigovor kao opći redoviti pravni lijek u hrvatsko upravno pravo uveden je tek Zakonom o općem upravnom postupku iz 2009. godine, koji je na snagu stupio 1. siječnja 2010. godine.

32 Međutim, za razliku od žalbe, prigovor nije opće dopušten pravni lijek pa se može izjaviti samo u slučajevima propisanima zakonom. Tako prigovor na značenju posebno dobiva u slučajevima zaštite građana od postupanja javnopravnih tijela, u slučajevima zaštite interesa osobe koja je dala inicijativu za pokretanje upravnog postupka po službenoj dužnosti kao i javnog interesa, u slučajevima zaštite prava korisnika javnih usluga te u slučaju neispunjavanja ugovornih obveza javnopravnog tijela iz upravnog ugovora. Đerđa, Dario, Opći upravni postupak u Republici Hrvatskoj, Inženjerski biro, Zagreb, 2010., str. 273.

33 Članak 122., stavci 1. i 3. Zakona o općem upravnom postupku.

34 Ako nema drugostupanjskog tijela protiv rješenja prvostupanjskog tijela o prigovoru može se izravno pokrenuti upravni spor. Članak 122., stavak 4. Zakona o općem upravnom postupku.

35 Đerđa, op. cit., str. 274. 
Dr. sc. Dario Đerđa i dr. sc. Teodor Antić: Nadzor nad radom izvršnih i upravnih tijela jedinica... Zbornik radova Pravnog fakulteta u Splitu, god. 53, 1/2016., str. 165.-205.

Međutim, vezano uz institut prigovora, svakako treba upozoriti na nedostatnu pravnu regulaciju u Zakonu o općem upravnom postupku o postupanju čelnika odnosno nadležnog javnopravnog tijela po prigovoru. Prilikom odlučivanja o prigovoru, čelnik odnosno nadležno javnopravno tijelo nedvojbeno se treba pridržavati ograničenja iz važećih propisa, ali svakako treba i koristiti ovlasti sadržane u tim propisima. Iako olakšavajuću okolnost predstavlja činjenica da se u povodu prigovora ne odlučuje o zakonitosti rješenja pa ne postoji niti dvojba o potrebi ili dopustivosti poništenja, ukidanja ili izmjene tog rješenja, činjenica da o prigovoru odlučuje javnopravno tijelo koje je taj prigovor i izazvalo odnosno čelnik toga tijela, omogućuje da se dodatnim djelovanjem istog tijela postupi po zakonu i otklone razlozi izjavljivanja prigovora. $\mathrm{Na}$ taj način osoba koja je izjavila prigovor na brz i učinkovit način trebala bi moći ostvariti svoje pravo odnosno pravni interes, a čelnik koji obavlja nadzor raspolaže širokim ovlastima utvrđivanja povrede zakonitosti i pravilnosti, uklanjanja ove povrede te, konačno, donošenja odluke o nastavku započetoga postupanja. ${ }^{36}$

No, kao što je ranije naglašeno, nadzor rada upravnih tijela jedinica lokalne samouprave ujedno se, kontinuirano i usustavljeno, provodi i unutar samih ovih tijela, a sukladno unaprijed propisanim mehanizmima. Za zakonitost $\mathrm{i}$ pravilnost rada javnopravnoga tijela odgovara čelnik toga tijela. ${ }^{37} \mathrm{U}$ jedinicama lokalne samouprave izvršni čelnik u općini jest općinski načelnik, a u gradu gradonačelnik. No, uz izvršnog čelnika poslove iz samoupravnog djelokruga u općinama i gradovima obavljaju i upravni odjeli i službe, koji se još nazivaju upravnim tijelima općina odnosno gradova. ${ }^{38} \mathrm{Uz}$ dužnost zastupanja općine i

36 Ibid., str. 274-276.

37 Takvo rješenje općeprihvaćeno je u pravnom sustavu Republike Hrvatske. Kao pravilo susreće se na središnjoj državnoj razini, ali i u drugim osobama javnoga prava i javnopravnim tijelima. Tako je primjerice zakonom propisano kako ministar predstavlja ministarstvo i upravlja njegovim radom te da, pored ostalih poslova, osobito brine o zakonitom i pravodobnom izvršavanju zakona. Istu dužnost imaju i predstojnik državnog ureda, ravnatelj državne upravne organizacije te predstojnik ureda državne uprave u jedinici područne (regionalne) samouprave. Ove osobe ujedno su dužne poduzimati mjere za osiguranje učinkovitosti u radu, raspoređivati poslove i davati naputke za rad, brinuti se o stručnom osposobljavanju i usavršavanju državnih službenika i namještenika u tijeku službe i o urednom i pravilnom korištenju imovine i sredstava za rad te poduzimati mjere utvrđene zakonom i drugim propisom za utvrđivanje odgovornosti za povrede službene dužnosti. Članak 39., stavak 1., točka 3.; članak 45., stavak 3., točka 3.; članak 51., stavak 3., točka 3. i članak 57., stavak 1., točka 2. Zakona o sustavu državne uprave, Narodne novine, br. 150/11. i 12/13. Slično je i u ustanovi, kao vrlo čestom ustrojstvenom obliku u kojemu se obavljaju poslovi iz nadležnosti jedinica lokalne samouprave. Ravnatelj je dužan organizirati i voditi rad i poslovanje ustanove, predstavljati i zastupati ustanovu, poduzimati sve pravne radnje u ime i za račun ustanove, zastupati ustanovu u svim postupcima pred sudovima, upravnim i drugim državnim tijelima te pravnim osobama s javnim ovlastima. Ravnatelj je ujedno i osoba odgovorna za zakonitost rada ustanove u cjelini. On vodi stručni rad ustanove te odgovora za takav rad, ako s obzirom na djelatnost i opseg rada nije određeno zakonom ili aktom o osnivanju da su poslovodna funkcija i funkcija vođenja stručnog rada ustanove razdvojeni. Članak 37., stavci 2. i 6. Zakona o ustanovama, Narodne novine, br. 76/93., 29/97., 47/99. i $35 / 08$.

38 Tijela jedinice lokalne i područne samouprave, sukladno člancima 27. do 48. te 53. do 66. Zakona o lokalnoj i područnoj (regionalnoj) samoupravi jesu općinsko vijeće, gradsko vijeće, županijska skupština i Skupština Grada Zagreba, kao predstavnička tijela, zatim općinski načelnik, gradonačelnik i župan kao izvršna tijela te upravni odjeli, službe i druga upravna tijela, kao upravna tijela. O ovome vidi i Rajko, 
Dr. sc. Dario Đerđa i dr. sc. Teodor Antić: Nadzor nad radom izvršnih i upravnih tijela jedinica... Zbornik radova Pravnog fakulteta u Splitu, god. 53, 1/2016., str. 165.-205.

grada, općinski načelnik odnosno gradonačelnik obavlja brojne poslove utvrđene statutom općine, grada, odnosno županije u skladu sa zakonom. Neke od takvih najvažnijih zadaća općinskog načelnika odnosno gradonačelnika svakako su vođenje računa o izvršavanju općih akata predstavničkog tijela općine odnosno grada, na način i u postupku propisanom statutom jedinice lokalne samouprave te obavljanje nadzora nad zakonitošću rada upravnih tijela koja obavljaju poslove iz samoupravnog djelokruga, ali i prenijetih poslova državne uprave, ${ }^{39}$ kao i obavljanje nadzora nad zakonitošću rada tijela mjesnoga odbora. ${ }^{40}$ No, nadzorne ovlasti općinskog načelnika odnosno gradonačelnika nisu usmjerene samo na upravna tijela koja obavljaju izvršne poslove već ove osobe posebne ovlasti imaju i prema predstavničkom tijelu. ${ }^{41}$ Hijerarhijski sustav odgovornosti u lokalnoj samoupravi olakšava čelniku provedbu ovoga nadzora. Zakonom o službenicima i namještenicima u lokalnoj i područnoj (regionalnoj) samoupravi utvrđeno je kako je službenik koji upravlja upravnim tijelom ili ustrojstvenom jedinicom odgovoran za vlastiti rad, ali i za rad službenika u upravnom tijelu ili ustrojstvenoj jedinici kojom upravlja, čime se zakonitosti i pravilnosti rada posebno daje na značenju. ${ }^{42}$

Kako bi se nadzor unutar samoga javnopravnoga tijela pravilno proveo, nužno je poduzeti niz radnji. $U$ tu je svrhu ponajprije potrebno utvrditi mjerila za ocjenjivanje rezultata odnosno djelatnosti svakoga radnoga mjesta u javnopravnome tijelu u usporedbi s ciljem i propisima. Nužno je utvrditi osobna zaduženja i odgovornosti svakoga službenika zaposlenoga na pojedinome radnome mjestu za rezultat rada odnosno radnje koje poduzima. Nadalje, potrebno je osigurati način prikupljanja podataka potrebnih za nadzor i način njihove usporedbe $s$ ranije postavljenim mjerilima. Konačno, potrebno je još utvrditi

Alen, „Javnopravna tijela prema novom Zakonu o upravnim sporovima“, Hrvatska pravna revija, god. 12., br. 1., 2012., str. 80-81.

39 Tijelima jedinica lokalne i područne (regionalne) samouprave te pravnim osobama koje imaju javne ovlasti, može se povjeriti obavljanje poslova državne uprave: rješavanje u upravnim stvarima u prvom i drugom stupnju, vođenje očevidnika određenih zakonom i drugim propisima i izdavanje propisanih uvjerenja i drugih potvrda te obavljanje drugih poslova državne uprave koji su im zakonom izrijekom stavljeni u nadležnost. Članak 60. i 61. Zakona o sustavu državne uprave.

40 U tom svojstvu općinski načelnik odnosno gradonačelnik mogu raspustiti vijeće mjesnog odbora, ako ono učestalo krši statut jedinice lokalne samouprave, pravila mjesnog odbora ili ne izvršava povjerene mu poslove. Vidi članak 39., stavak 1.; članak 53., stavak 1.; članak 42., stavci 1. do 3.; članak 64. i članak 74. Zakona o lokalnoj i područnoj (regionalnoj) samoupravi.

${ }_{41}$ Tako općinski načelnik odnosno gradonačelnik u obavljanju poslova iz samoupravnog djelokruga općine odnosno grada ima pravo obustaviti od primjene opći akt predstavničkog tijela. Ako ocijeni da je tim aktom povrijeđen zakon ili drugi propis, općinski načelnik odnosno gradonačelnik donijet će odluku o obustavi općeg akta u roku od osam dana od dana donošenja općeg akta. Općinski načelnik odnosno gradonačelnik tada ima pravo od predstavničkog tijela zatražiti da u roku od osam dana od donošenja odluke o obustavi otkloni uočene nedostatke u općem aktu, a ako predstavničko tijelo to ne učini, općinski načelnik odnosno gradonačelnik dužan je bez odgode o tome obavijestiti predstojnika ureda državne uprave u županiji i dostaviti mu odluku o obustavi općeg akta. Predstojnik ureda državne uprave tada će, u roku od osam dana od zaprimanja, ocijeniti osnovanost odluke općinskog načelnika odnosno gradonačelnika o obustavi od primjene općeg akta. Članak 42., stavci 4. do 6. Zakona o lokalnoj i područnoj (regionalnoj) samoupravi. No, kako nadzorne ovlasti nad predstavničkim tijelom jedinice lokalne samouprave nisu predmet ovoga rada, neće se detaljnije analizirati.

42 Članak 33. Zakona o službenicima u lokalnoj i područnoj (regionalnoj) samoupravi. 
Dr. sc. Dario Đerđa i dr. sc. Teodor Antić: Nadzor nad radom izvršnih i upravnih tijela jedinica... Zbornik radova Pravnog fakulteta u Splitu, god. 53, 1/2016., str. 165.-205.

korektivne mehanizme kojima će se ispraviti nedostaci utvrđeni nadzorom. ${ }^{43}$ Tek ako su poduzete sve ove radnje može se govoriti o unutarnjem nadzoru što ga provodi čelnik ili drugi rukovoditelj upravnog tijela. Važno je naglasiti kako unutarnji nadzor rada javnopravnoga tijela treba biti konstantan i objektivan, što znači da se treba provoditi stalno, sukladno unaprijed utvrđenim i propisanim pravilima, od strane osoba posebno osposobljenih za obavljanje ove aktivnosti. ${ }^{44}$ Nije isključeno da se u pojedinim javnopravnim tijelima, što je čest slučaj i u nekim javnim ustanovama, u svrhu provedbe unutarnjega nadzora utvrde posebna tijela koja prate zakonitost i pravilnost rada zaposlenika, čelnika upozoravaju na potencijalne nezakonitosti i nepravilnosti u radu pojedinih službenika te predlažu mjere za njihovo otklanjanje. ${ }^{45}$

Osiguravanju zakonitosti i pravilnosti u radu tijela lokalne samouprave pridonose i načela propisana Zakonom o službenicima i namještenicima $u$ lokalnoj i područnoj (regionalnoj) samoupravi, kao npr. nalaganje službeniku dužnosti savjesno obavljati poslove, pridržavajući se Ustava, zakona, drugih propisa i pravila struke, nalaganje službeniku u radu koristiti nova saznanja, usvajati i primjenjivati stručna dostignuća te se trajno stručno usavršavati. ${ }^{46}$ Inzistiranje na zakonitom i pravilnom radu službenika, ali i na pridržavanju pravila struke te odgovornom izvršavanju radnih zadaća, posebno je osnaženo institutom odgovornosti službenika za povrede službene dužnosti. Tako Zakon o službenicima i namještenicima u lokalnoj i područnoj (regionalnoj) samoupravi neizvršavanje, nesavjesno, nepravodobno ili nemarno izvršavanje službeničkih obveza; nezakoniti rad ili propuštanje poduzimanja mjera ili radnji na koje je službenik ovlašten radi sprečavanja nezakonitosti; davanje netočnih podataka

43 Pusić ukazuje kako s vremenom cilj i način provedbe nadzora evaluira te se mijenjanjem odnosa u upravi mijenja i sadržaj same funkcije nadzora. On se od primjene vlasti u sklopu unutarnjih odnosa u javnopravnim tijelima sve više pretvara u stručnu djelatnost određivanja kriterija uspješnosti, mjerenja odstupanja od tih kriterija i ispravljanja ovih odstupanja, čime od nadzora nad radom službenika prerasta u nadzor nad objektivnim tijekovima i procesima. Pusić, Nauka..., op. cit., str. 347.

44 Odgovarajući koncepti unutarnjega nadzora susreću se i u usporednom pravu. Tako npr. u Italiji svaka jedinica lokalne samouprave mora imati ustrojen sustav unutarnjeg nadzora, koji će voditi računa da tijelo lokalne samouprave poduzima upravne radnje na učinkovit i ekonomičan način. Štoviše, od 2009. godine u ovoj državi svako tijelo lokalne samouprave, samostalno ili u suradnji s drugim tijelima, mora angažirati neovisno tijelo koje će nadzirati njegov rad. Takvo tijelo zaduženo je nadzirati provedbu evaluacijskog sustava, transparentnost te sustav unutarnjeg nadzora tijela lokalne samouprave. Ujedno, izvršnim tijelima lokalne samouprave, baš kao i nacionalnom odboru osnovanom na nacionalnoj razini za praćenje evaluacija, transparentnosti i integriteta javne uprave, dostavlja izvješća o svojim zapažanjima. Vidi Vandelli, Luciano, „Local government in Italy“, Local government in the Member States of the European Union: a comparative legal perspective, National institute for public administration, Madrid, 2012., str. 359-360.

45 Takav slučaj zakonom je predviđen u svezi s visokim učilištima. Zakonom o osiguranju kvalitete u znanosti i visokom obrazovanju, Narodne novine, br. 45/09., propisano je kako svaka ustanova u sustavu znanosti i visokog obrazovanja svojim općim aktom uređuje unutarnji sustav osiguravanja i unapređivanja kvalitete. Unutarnji sustav osiguravanja i unapređivanja kvalitete predstavlja sustav mjera i aktivnosti kojima ustanove u znanosti i visokom obrazovanju osiguravaju svoju odgovornost za učinkovitost $i$ ostvarivanje kvalitetnih ishoda obrazovnih i znanstvenih aktivnosti. Clanak 2., točka 2. te članak 18 , stavci 5. i 6 . Zakona o osiguranju kvalitete u znanosti i visokom obrazovanju.

46 Članak 33. Zakona o službenicima u lokalnoj i područnoj (regionalnoj) samoupravi. 
kojima se utječe na donošenje odluka ili nastup štetnih posljedica; zlouporabu položaja; prekoračenje ovlasti u službi; odbijanje izvršenja zadaće ako za to ne postoje opravdani razlozi; neovlaštenu poslugu sredstvima povjerenima za izvršavanje poslova; uništenje, otuđenje ili činjenje dostupnim podatka, u vezi s obavljanjem službe, s utvrđenim stupnjem tajnosti u skladu s posebnim zakonom; obavljanje djelatnosti koja je u suprotnosti s poslovima radnog mjesta ili bez prethodnog odobrenja pročelnika upravnog tijela, odnosno općinskog načelnika ili gradonačelnika; onemogućavanje građana ili pravnih osoba u ostvarivanju prava na podnošenje zahtjeva, žalbi, prigovora i predstavki ili u ostvarivanju drugih zakonskih prava; nedolično ponašanje koje nanosi štetu ugledu službe, ali i neke druge povrede - utvrđuje teškim povredama službene dužnosti. Pored ovih, Zakon neka djela, kao npr. učestalo zakašnjavanje na posao ili raniji odlazak s posla; napuštanje radnih prostorija tijekom radnog vremena bez odobrenja ili opravdanog razloga; neuredno čuvanje spisa, podataka ili druge povjerene dokumentacije i sl. - utvrđuje lakim povredama službene dužnosti. Odgovornost službenika za teške povrede službene dužnosti u prvom stupnju rješenjem utvrđuje službenički sud, a u drugom stupnju Viši službenički sud ustrojen za državne službenike. Lake povrede službene dužnosti u prvom stupnju rješenjem utvrđuje pročelnik upravnog tijela ili službena osoba kojoj je rješavanje o tome utvrđeno opisom poslova radnog mjesta, a u drugom stupnju nadležni službenički sud. ${ }^{47} \mathrm{U}$ slučaju utvrđene teške povrede službene dužnosti, službenik može biti kažnjen novčanom kaznom na vrijeme od jednog do šest mjeseci, u mjesečnom iznosu do 20 \% ukupne plaće isplaćene u mjesecu u kojem je kazna izrečena; premještajem na radno mjesto niže složenosti poslova, unutar iste stručne spreme; uvjetnom kaznom prestanka službe; pa čak i prestankom službe. Za lake povrede službene dužnosti službeniku se kao kazna može izreći opomena; javna opomena koja se objavljuje na oglasnoj ploči upravnog tijela u kojem je službenik zaposlen; ili novčana kazna u visini do $10 \%$ plaće službenika isplaćene u mjesecu kad je kazna izrečena. Ovim se mjerama u Hrvatskoj nastojalo posebno doprinijeti zakonitom i pravilnom radu službenika. Štoviše, odgovornost službenika posebno je naglašena obvezom službenika da naknadi štetu koju je u službi ili u vezi sa službom namjerno ili iz krajnje nepažnje nanio jedinici lokalne samouprave. ${ }^{48}$

Uz stegovnu odgovornost, nerijetko praćenu regresnom obvezom naknade štete, u nekim jedinicama lokalne samouprave postupanju, ali i ophođenju samih službenika pridaje se dodatni značaj. Tako su u nekim jedinicama doneseni tzv. etički kodeksi, kojima se uređuju etičkanačela i pravila dobrog ponašanja službenika i namještenika zaposlenih u njihovim upravnim tijelima. Etički kodeks sadrži

47 Iznimno, o lakim povredama službene dužnosti pročelnika upravnog tijela u prvom stupnju odlučuju općinski načelnik, gradonačelnik, odnosno župan.

48 Vidi članak 43., stavak 1., članak 45., članak 46., članak 47., članak 61., stavak 1., članak 64., članak 65. te članak 71. Zakona o službenicima i namještenicima u lokalnoj i područnoj (regionalnoj) samoupravi. Stegovna odgovornost službenika zaposlenih u tijelima lokalne samouprave jedan je od važnih nadzornih mehanizama i u Grčkoj. O ovome vidi Hlepans, Nikolaos-Komninos, „Local government in Greece“, Local government in the Member States of the European Union: a comparative legal perspective, National institute for public administration, Madrid, 2012., str. 279. 
pravila dobrog ponašanja službenika i namještenika u odnosima prema fizičkim i pravnim osobama kao i u međusobnim odnosima službenika i namještenika. Svrha mu je da se dosljednom provedbom njegovih odredbi uspostavi primjerena razina poslovne kulture te stvori ozračje u kojem je, uz zaštitu javnog interesa, svim fizičkim i pravnim osobama, strankama u postupku te drugim tijelima kao korisnicima usluga, zajamčeno učinkovito ostvarivanje prava i pravnih interesa, a službenicima i namještenicima dostojanstvo rada. Sukladno odredbama kodeksa, građani i pravne osobe te službenici i namještenici mogu posebno imenovanom povjereniku za etiku podnijeti pritužbu na ponašanje službenika i namještenika, za koje smatraju da je protivno odredbama kodeksa, a po provedenom postupku u utvrđivanju etičke odgovornosti takav službenik snosi odgovarajuće sankcije. ${ }^{49}$

Konačno, na kvalitetu rada službenika, pa tako i na zakonitost i pravilnost njihova rada utječe još jedan mehanizam propisan Zakonom o službenicima i namještenicima u lokalnoj i područnoj (regionalnoj) samoupravi - ocjenjivanje službenika. Službenici se ocjenjuju svake godine za prethodnu kalendarsku godinu. Službenike ocjenjuje pročelnik upravnog tijela, a pročelnika ocjenjuje općinski načelnik odnosno gradonačelnik. Ocjena službenika temelji se na podacima o stručnom znanju pokazanom u obavljanju poslova, učinkovitosti i kvaliteti rada te poštovanju službene dužnosti. Službenici se ocjenjuju rješenjem koje sadrži jednu od sljedećih ocjena: odličan, vrlo dobar, dobar, zadovoljava i ne zadovoljava. Službenika koji je ocijenjen ocjenom „,ne zadovoljava“, upućuje se na dodatno stručno osposobljavanje ili se premješta na drugo radno mjesto. Službeniku koji je dva puta uzastopce ocijenjen ocjenom ,ne zadovoljava“ prestaje služba po sili zakona, danom izvršnosti zadnjega rješenja o ocjenjivanju. Dobre ocjene rada službenika utjecaj imaju pri raspoređivanju na druga radna mjesta, pri čemu prednost ima bolje ocijenjeni službenik. ${ }^{50}$

Svim ovim mehanizmima, od kojih se neki iniciraju od pojedinaca koji smatraju kako su im prava i pravni interesi povrijeđeni, dok se drugi provode usustavljeno i kontinuirano, nastoje se učinkovito i ekonomično otkloniti nezakonitosti i nepravilnosti u radu izvršnih i upravnih tijela jedinica lokalne samouprave uz apsolutno poštovanje njihovih samoupravnih ovlasti.

\section{UPRAVNI NADZOR NAD IZVRŠNIM I UPRAVNIM TIJELIMA LOKALNE SAMOUPRAVE}

Kada se razmatra upravni nadzor nad izvršnim i upravnim tijelima jedinica lokalne samouprave, dade se uočiti niz problema teorijske i praktične naravi. Iako se već odavno ističe kako se upravo državnim nadzorom nad lokalnom i

49 Takvi akti usvojeni su npr. u Gradu Rijeci i Gradu Koprivnici. Vidi Etički kodeks službenika i namještenika upravnih tijela Grada Rijeke, Službene novine Primorsko-goranske županije, br. 54/12., Etički kodeks službenika i namještenika Grada Koprivnice, Glasnik Grada Koprivnice, br. 1/15.

50 Članci 94. do 97. te članak 105., stavak 2. Zakona o službenicima i namještenicima u lokalnoj i područnoj (regionalnoj) samoupravi. 
Dr. sc. Dario Đerđa i dr. sc. Teodor Antić: Nadzor nad radom izvršnih i upravnih tijela jedinica... Zbornik radova Pravnog fakulteta u Splitu, god. 53, 1/2016., str. 165.-205.

područnom (regionalnom) samoupravom osigurava načelo jedinstva javne uprave u državi te da se upravo tako može jamčiti da će tijela lokalne i područne (regionalne) samouprave pravilno obavljati svoje ovlasti i obveze, ovdje se otvara važan doktrinarni problem. Nadzorom tijela državne uprave nad tijelima jedinica lokalne i područne (regionalne) samouprave državna uprava jednostavno može zadrijeti u samoupravne ovlasti ovih drugih te rezultirati faktičnom uskratom nekih samoupravnih prava jedinica lokalne i područne (regionalne) samouprave. ${ }^{51}$ Stoga se u pravnoj doktrini državni nadzor nad jedinicama lokalne i područne (regionalne) samouprave strogo razlikuje od hijerarhijskog nadzora višeg tijela državne upravne nad nižim tijelom državne uprave. Upravo su stoga utvrđena i posebna načela državnog nadzora koja se primjenjuju na samoupravni djelokrug jedinica lokalne i područne (regionalne) samouprave, dok za nadzor zakonitosti rada prenesenih poslova vrijede pravila hijerarhijskog nadzora unutar državne uprave. $^{52}$

Uspostava odgovarajućeg državnog nadzora nad lokalnom samoupravom posebice je složena u sustavima koji imaju velik broj razmjerno malih jedinica lokalne samouprave $\mathrm{s}$ međusobno vrlo različitim prirodnim i gospodarskim uvjetima te materijalnim, financijskim, kadrovskim i drugim potencijalima, kao što je to slučaj u Hrvatskoj. Prekomjerni državni nadzor lako može ugušiti samoupravu, a njezina upravna tijela pretvoriti u podređene područne državne urede čime se faktično izjednačava s hijerarhijskim nadzorom višeg državnog

51 Krbek je isticao da ,iako su samouprava i državni nadzor pojmovno dvije posve oprečne stvari, one nužno postoje zajedno i žive zajedničkim životom“. Krbek, Državni ..., op. cit., str. 289. Slično, Grafenauer smatra kako država ne bi mogla funkcionirati kao cjelina, kada bi lokalna uprava i samouprava bile organizirane tako da svoje zadaće obavljaju bez utjecaja i nadzora središnje državne vlasti. Tada se ne bi niti moglo govoriti o državi i njezinim dijelovima, već o više država, a država ne bi predstavljala područje jedinstvenog pravnog poretka, već bi postojalo toliko pravnih poredaka koliko bi bilo samoupravnih lokalnih jedinica. Grafenauer, Božo, Lokalna samouprava na Slovenskem - teritorijalno-organizacijske strukture, Univerza v Mariboru, Pravna fakulteta v Mariboru, Maribor, 2000., str. 67.

52 Tako je člankom 69. Zakona o sustavu državne uprave utvrđeno kako središnja tijela državne uprave u svom djelokrugu nadziru rad tijela jedinica lokalne i područne (regionalne) samouprave i pravnih osoba s javnim ovlastima u obavljanju poslova državne uprave i u tom svojstvu u ovlasti su osobito: nadzirati zakonitost, pravodobnost i pravilnost obavljanja povjerenih poslova državne uprave; raspraviti stanje u pojedinom tijelu jedinice lokalne i područne (regionalne) samouprave ili pravnoj osobi koja ima javne ovlasti te odrediti mjere koje su to tijelo ili pravna osoba koja ima javne ovlasti dužni poduzeti radi izvršavanja poslova državne uprave, a osobito obustaviti od izvršenja opće akte tijela jedinica lokalne $i$ područne (regionalne) samouprave i pravnih osoba s javnim ovlastima u povjerenim im poslovima državne uprave; pokrenuti postupak za utvrđivanje odgovornosti službenika i namještenika tijela jedinica lokalne i područne (regionalne) samouprave, odnosno pravnih osoba koje imaju javne ovlasti; poduzeti i druge mjere u skladu sa zakonom i drugim propisima. Kako bi potreba za nadzorom, a posebno korištenjem nadzornih ovlasti bila što manja, tijela državne uprave dužna su u obavljanju poslova državne uprave surađivati s tijelima jedinica lokalne i područne (regionalne) samouprave i uprave i pravnim osobama koje imaju javne ovlasti i pružati im stručnu pomoć, a osobito stručno obrađivati pitanja i pojave u svezi s provedbom zakona i drugih propisa, davati im stručna mišljenja i objašnjenja te održavati stručna savjetovanja o načinu provedbe zakona kao i o drugim općim pitanjima od značaja za pravilno djelovanje i unapređivanje načina i učinkovitosti rada u poslovima državne uprave. Nadzor nad poslovima koji su s države preneseni na jedinice lokalne samouprave državna tijela provode npr. i u Belgiji i Češkoj. Vidi Bouvier, Jacques, „Local government in Belgium“, str. 61. i Kadečka, Stanislav, „Local government in Czech Republic", str. 128., sve u: Local government in the Member States of the European Union: a comparative legal perspective, National institute for public administration, Madrid, 2012. 
Dr. sc. Dario Đerđa i dr. sc. Teodor Antić: Nadzor nad radom izvršnih i upravnih tijela jedinica... Zbornik radova Pravnog fakulteta u Splitu, god. 53, 1/2016., str. 165.-205.

tijela nad nižim, slijedom čega je samouprava i u pravnom i u političkom smislu dovedena u pitanje. Stoga ovlasti nadzornih državnih tijela nad tijelima lokalne samouprave nužno trebaju biti ograničenije negoli je to slučaj kod hijerarhijskog nadzora unutar državne uprave. Nadzorne ovlasti središnjih državnih tijela nad jedinicama lokalne i područne (regionalne) samouprave svode se na sprečavanje nezakonitog djelovanja te na prinuđivanje ovih tijela na obavljanje zadaća iz svoje nadležnosti. Dok se ovlasti koje postoje kod hijerarhijskog nadzora unutar državne uprave trebaju tumačiti ekstenzivno, nadzorne ovlasti pri nadzoru središnjih državnih tijela nad tijelima lokalne samouprave trebaju se tumačiti restriktivno. ${ }^{53}$

Zakonom o lokalnoj i područnoj (regionalnoj) samoupravi propisano je kako država, radi zaštite ustavnosti i zakonitosti i radi zaštite prava građana, obavlja nadzor nad zakonitošću rada i akata tijela jedinica lokalne i područne (regionalne) samouprave. ${ }^{54}$ Dakle, nadzorne ovlasti države u Republici Hrvatskoj protežu se nad svim radnjama, odlukama i drugim aktima lokalne samouprave. Obveza države nadzirati zakonitost rada izvršnih i upravnih tijela lokalne samouprave ponekad je i posebno naglašena kao u slučaju u kojemu je propisano da je Ministarstvo financija, odnosno drugo zakonom određeno tijelo, ovlašteno nadzirati zakonitost materijalnog i financijskog poslovanja jedinica lokalne samouprave i jedinica područne (regionalne) samouprave ili u slučaju u kojem je propisano kako nadzor zakonitosti pojedinačnih neupravnih akata koje u samoupravnom djelokrugu donose predstavnička i izvršna tijela općina, gradova i županija obavljaju nadležna središnja tijela državne uprave, svatko u svojem djelokrugu, sukladno posebnom zakonu. ${ }^{55} \mathrm{U}$ provedbi ovoga nadzora nadležno tijelo čak je ovlašteno oglasiti pojedinačni neupravni akt ništavim, ako je akt donijelo neovlašteno tijelo, ako su u postupku donošenja akta povrijeđeni zakon, statut ili drugi opći akt jedinice, ako se akt odnosi na pitanje koje nije u djelokrugu jedinice lokalne i područne (regionalne) samouprave ili ako je nepravilno primijenjen zakon ili drugi propis,

53 Vidi Antić, Nadzor $i$..., op. cit., str. 363-364.

54 Postoje određene ingerencije države nad lokalnom samoupravom koje obavljaju državna tijela, $u$ prvom redu ministarstva. Tako npr. Ministarstvo vanjskih i europskih poslova obavlja upravne i stručne poslove koji se odnose na koordinaciju tijela državne uprave i tijela lokalne i područne (regionalne) samouprave u poslovima iz njihova djelokruga koji su vezani s Europskom unijom, Ministarstvo regionalnoga razvoja i fondova Europske unije surađuje i koordinira potrebne aktivnosti s jedinicama lokalne i regionalne (područne) samouprave u pripremi, organizaciji i provedbi razvojnih programa $\mathrm{i}$ projekata, dok Ministarstvo uprave obavlja upravne i stručne poslove koji se odnose na sustav i ustrojstvo lokalne i područne (regionalne) samouprave, radnopravni položaj zaposlenih u lokalnoj i područnoj (regionalnoj) samoupravi; poslove upravnog i inspekcijskog nadzora u svim tijelima lokalne i područne (regionalne) samouprave; upravljanje sredstvima za unapređenje upravne sposobnosti kroz razvoj uslužne kulture u upravi; usmjeravanje reformi i procesa modernizacije, primjenu etičkih načela, ostvarivanje međunarodne suradnje u pitanjima upravnog prava u lokalnoj samoupravi i sl. Međutim, ovi poslovi ne uključuju i nadzor ovih tijela nad zakonitošću rada lokalne samouprave. Vidi članak 7., stavak 4.; članak 10., stavak 1. i članak 12., stavak 1. Zakona o ustrojstvu i djelokrugu ministarstva i drugih središnjih tijela državne uprave, Narodne novine, br. 150/11., 22/12., 39/13., 125/13. i 148/13.

55 Članci 72., 77b. i 78. Zakona o lokalnoj i područnoj (regionalnoj) samoupravi. 
Dr. sc. Dario Đerđa i dr. sc. Teodor Antić: Nadzor nad radom izvršnih i upravnih tijela jedinica... Zbornik radova Pravnog fakulteta u Splitu, god. 53, 1/2016., str. 165.-205.

odnosno opći akt. ${ }^{56}$ No, pri tome je nadzor usmjeren samo na nadzor zakonitosti, a ne i na pravilnosti takvih odluka. ${ }^{57}$

Međutim, od nadzora koji nad tijelom jedinice lokalne i područne (regionalne) samouprave obavlja državna uprava, treba razlikovati nadzor koji nad takvim tijelom provodi drugo, hijerarhijski više samoupravno tijelo. Takav se nadzor u Hrvatskoj nad jedinicama lokalne samouprave ustrojava od tijela područne (regionalne) samouprave. ${ }^{58}$ On ima tendenciju širenja na hijerarhijski nadzor, a za tijela jedinica lokalne samouprave u pravilu je mnogo prihvatljiviji od nadzora koji provodi državna uprava. Razlog je tomu što između nižeg i višeg tijela jedinice lokalne i područne (regionalne) samouprave ne postoji načelna opreka koja inače postoji između lokalne i područne (regionalne) samouprave i državne uprave. ${ }^{59}$ Tako, primjerice, županijska tijela provode nadzor nad postupcima u kojima izvršna i upravna tijela jedinica lokalne samouprave u prvom stupnju rješavaju o određenim pravima, obvezama i pravnim interesima fizičkih i pravnih osoba (upravnim stvarima) u područjima komunalnog gospodarstva, socijalne skrbi, lokalnih poreza, gospodarenja otpadom, odgoja i obrazovanja, legalizacije nezakonito izgrađenih objekata i zgrada i dr.

Ovaj hijerarhijski nadzor tijela jedinica područne (regionalne) samouprave nad izvršnim i upravnim tijelima jedinica lokalne samouprave posebno do izražaja dolazi u rješavanju upravih stvari u žalbenom postupku. Žalba u upravnom postupku jedini je redoviti pravni lijek protiv odluke o upravnoj stvari. U pravnoj doktrini naglašava se kako je pravo na žalbu iznimno važno postupovno pravo stranke, jer upravo izjavljivanjem žalbe ona često može zaštititi svoja prava

56 Ako je u postupku donošenja akta povrijeđen zakon, statut ili drugi opći akt jedinice ovlašteno tijelo može donijeti rješenje u roku od godine dana od donošenja pojedinačnog akta. Protiv rješenja kojim se pojedinačni neupravni akt proglašava ništavim nije dopuštena žalba, ali se može pokrenuti upravni spor pred nadležnim upravnim sudom.

57 U Austriji nadzor nad izvršnim i upravnim tijelima lokalne samouprave također obuhvaća isključivo nadzor zakonitosti te se nadzire samo jesu li izvršna i upravna tijela lokalne samouprave svojim odlukama i postupanjima prekršila zakone i druge opće akte ili prekoračila svoje ovlasti. Isključivo nadzor zakonitosti nad radom izvršnih i upravnih tijela lokalne samouprave provodi se još, primjerice, u Danskoj, Njemačkoj i Litvi. Drukčije je u Belgiji gdje se pri obavljanju nadzora ne utvrđuje samo postupaju li izvršna i upravna tijela jedinica lokalne samouprave zakonito, već i vode li računa o javnome interesu, tj. postupaju li svrhovito, čime se ovaj nadzor, u neku ruku, protivi načelima autonomije lokalne samouprave. Vidi Gamper, Anna, „Local Government in Austria“, str. 39., Greve, Emil, „Local government in Denmark“, str. 151., Schefold, Dian, „Local government in Germany“, str. 249., Šaparniene, Diana, Lazauskiene, Aiste, „Local government in Lithuania“, str. 406., sve u: Local government in the Member States of the European Union: a comparative legal perspective, National institute for public administration, Madrid, 2012. te Bouvier, op. cit., str. 62-63.

58 U Austriji nadzor nad izvršnim i upravnim tijelima jedinica lokalne samouprave također u pravilu provode okružna, tj. područna tijela, baš kao i u Mađarskoj i Poljskoj gdje ovaj nadzor provode tijela regionalne samouprave. Postoje i slučajevi u kojima državna tijela mogu provoditi upravni nadzor nad tijelima lokalne samouprave, kao što je to npr. u Finskoj, no samo kada je to izričito propisano zakonom. Vidi Gamper, op. cit., str. 39. te Szente, Zoltan, „Local government in Hungary“،, str. 304., Kulesza, Michal, Szescilo, Dawid, „Local government in Poland“, str. 500. i Mäenpää, Olli, „Local government in Finland", str. 199., sve u: Local government in the Member States of the European Union: a comparative legal perspective, National institute for public administration, Madrid, 2012.

59 Krbek, Osnovi..., op. cit., str. 40. 
Dr. sc. Dario Đerđa i dr. sc. Teodor Antić: Nadzor nad radom izvršnih i upravnih tijela jedinica... Zbornik radova Pravnog fakulteta u Splitu, god. 53, 1/2016., str. 165.-205.

i pravne interese, pokrećući pred drugostupanjskim tijelom postupak ocjene zakonitosti i pravilnosti rada tijela koje je u prvom stupnju odlučivalo o njezinim pravima i obvezama. Time se žalba javlja kao snažno pravno sredstvo u zaštiti prava i pravnih interesa stranke, ali i javnog interesa uopcee. ${ }^{60}$ Cilj izjavljivanja žalbe jest osporiti zakonitost ili pravilnost donesenog prvostupanjskog rješenja ujedno zahtijevajući od nadležne više upravne instance - drugostupanjskog tijela - da to rješenje poništi ili izmijeni kada god utvrdi da je upravna stvar trebala biti riješena drukčije negoli je to učinilo prvostupanjsko tijelo. Žalba otvara mogućnost da o istoj upravnoj stvari odlučuju dvije instance - i prvostupanjsko i drugostupanjsko tijelo - što jamči ispravljanje eventualnih pogrešaka u donošenju prvostupanjskog rješenja, čime se osigurava jača zaštita prava i pravnih interesa stranke i drugih osoba o čijim se pravima ili obvezama u upravnom postupku odlučuje prvostupanjskim rješenjem, baš kao i jača zaštita javnog interesa. Prilikom žalbenog nadzora nadzorno tijelo raspolaže istim ovlastima koje ima nadzirano tijelo. Njegove ovlasti redovito se svode na pravo ponovnog meritornog rješavanja upravne stvari, iako se ono može opredijeliti i koristiti samo kao ovlast objektivnog stavljanja izvan snage te eventualno vratiti predmet na ponovno rješavanje prvostupanjskom tijelu. U pravilu, nadzorno tijelo tijekom nadzora ovdje ima ovlast u potpunosti preuzeti obavljanje poslova nadziranoga tijela. ${ }^{61}$ Pravo na žalbu u hrvatskom pravnom sustavu zauzima nezaobilazno mjesto te je dignuto čak na razinu ustavnog prava. ${ }^{62}$

U upravnom postupku žalba se može izjaviti protiv svakog prvostupanjskog rješenja, izuzev u slučajevima kada je zakonom isključena. ${ }^{63}$ Međutim, u upravnom postupku žalba se može izjaviti samo na rješenje, ali ne i na zaključak kao postupovnu odluku donesenu tijekom vođenja postupka. ${ }^{64}$ No, valja imati na umu kako se žalba može izjaviti samo protiv prvostupanjske odluke o upravnoj stvari, dok protiv drugostupanjske nije dopuštena, jer u Hrvatskoj ne postoji mogućnost trostupanjskog odlučivanja o istoj upravnoj stvari. Pored donesenog

60 Vidi Borković, Upravno..., op. cit., str. 407. te Krijan, Pero, „Komentar Zakona o općem upravnom postupku“, Novi informator, Zagreb, 2004., str. 321. Žalba kao redoviti pravni lijek ili neki njezini oblici susreće se u svim europskim pravnim sustavima.

61 Tomić, op. cit., str. 60.

62 Tako se člankom 18. Ustava Republike Hrvatske, Narodne novine, br. 56/90., 135/97., 113/00., 28/01., 76/10. i 5/14., jamči pravo na žalbu protiv pojedinačnih pravnih akata donesenih u postupku prvog stupnja pred sudom ili drugim ovlaštenim tijelom, a ovo pravo može se samo iznimno isključiti u zakonom propisanim slučajevima, ali jedino ukoliko je osiguran drugi vid pravne zaštite.

63 Članak 105., stavak 1. Zakona o općem upravnom postupku. Dakle, pravo na žalbu protiv prvostupanjskog rješenja donesenog u upravnom postupku nije moguće isključiti propisom podzakonske pravne snage. Slična rješenja susreću se i u usporednom pravu. Tako se primjerice u Češkoj utvrđuje pravo izjavljivanja žalbe protiv svakog akta, izuzev u zakonom propisanim slučajevima, kao i u Islandu gdje stranka također ima pravo na upravni akt izjaviti žalbu drugostupanjskom tijelu s ciljem stavljanja takvog akta izvan snage ili njegove izmjene, ako drukčije nije propisano zakonom ili, čak, utvrđeno pravnom praksom.

64 Slična rješenja susreću se i u usporednom pravu. Primjerice u Austriji se postupovne odluke ne mogu posebno osporavati žalbom, već se mogu osporavati samo žalbom protiv odluke o predmetu postupka. Slično je i na Islandu gdje se postupovna odluka može osporavati žalbom samo u okviru odluke o upravnoj stvari. 
Dr. sc. Dario Đerđa i dr. sc. Teodor Antić: Nadzor nad radom izvršnih i upravnih tijela jedinica... Zbornik radova Pravnog fakulteta u Splitu, god. 53, 1/2016., str. 165.-205.

rješenja u čiju se zakonitost i pravilnost sumnja, predmet je žalbe u upravnom postupku i šutnja uprave, tj. slučaj kada nadležno javnopravno tijelo nije donijelo rješenje u zakonom propisanom roku. ${ }^{65}$

Protiv pojedinačnih akata općinskih i gradskih upravnih tijela te pojedinačnih akata pravnih osoba donesenih u upravnim stvarima kojima su odlukom predstavničkog tijela općine ili grada povjerene javne ovlasti, može se izjaviti žalba nadležnom upravnom tijelu županije, ako posebnim zakonom nije drukčije propisano. Međutim, protiv pojedinačnih akata predstavničkog tijela, općinskog načelnika, gradonačelnika ili župana kojima se u upravnim stvarima rješava o pravima, obvezama i pravnim interesima fizičkih i pravnih osoba, ako posebnim zakonom nije drukčije propisano, žalba se ne može izjaviti, već se jedino može pokrenuti upravni spor. ${ }^{66}$

Kako je pravo žalbe postupovno pravo, i krug je osoba koje imaju pravo koristiti ovaj pravni lijek ograničen. Tako izjaviti žalbu može samo stranka u upravnom postupku. ${ }^{67}$ Dakle, osoba koja izjavljuje žalbu u konkretnom upravnom postupku mora imati stranačku legitimaciju, tj. prvostupanjsko rješenje mora imati pravni učinak na njezina prava, obveze ili pravne interese. Protiv rješenja kojim je povrijeđen zakon u korist pojedinca ili pravne osobe, a na štetu društvene zajednice, žalbu je ovlašten izjaviti i državni odvjetnik, kada god je na poduzimanje ove postupovne radnje ovlašten posebnim zakonom. On, dakle, nema opću ovlast izjaviti žalbu protiv prvostupanjskog rješenja, već njome raspolaže samo kada mu ovu ovlast izričito podjeljuje zakon. U žalbenom postupku prvostupanjsko rješenje može se osporavati iz sljedećih razloga: jer je doneseno od nenadležnog tijela; jer su u prvostupanjskom upravnom postupku povrijeđena pravila postupka koja mogu utjecati na rješenje upravne stvari; jer su činjenice pogrešno ili nepotpuno utvrđene, odnosno jer je iz pravilno i potpuno utvrđenih činjenica izveden pogrešan zaključak u svezi s činjeničnim stanjem; zbog pogrešne primjene pravnog propisa materijalnog prava na osnovi kojeg je riješena upravna stvar te zbog pogrešne primjene slobodne ocjene. Dakle, u žalbenom postupku nadziru se i formalna i materijalna zakonitost prvostupanjskog rješenja, odnosno kako pravilnost postupanja tako i pravilnost primjene materijalnih propisa na temelju kojih je riješena upravna stvar. Stoga se može ustvrditi kako se u žalbenom

65 Članak 105., stavak 2. Zakona o općem upravnom postupku.

${ }_{66}$ Članak 76., stavak 3. te članak 77.a Zakona o lokalnoj i područnoj (regionalnoj) samoupravi. Tijela ovlaštena rješavati u žalbenom postupku u različitim europskim državama određena su na najrazličitije načine. Tako se žalba kojom se osporava pojedinačni akt jedinice lokalne samouprave u Austriji podnosi saveznoj državi, u Grčkoj specijalnoj nadzornoj službi, a u Latviji resornom ministarstvu. Vidi Gamper, op. cit., str. 39., Hlepans, op. cit., str. 278. te Vilka, Inga, „Local government in Latvia“, Local government in the Member States of the European Union: a comparative legal perspective, National institute for public administration, Madrid, 2012., str. 383.

${ }^{67}$ Vidi članak 105. Zakona o općem upravnom postupku. Pravo izjaviti žalbu u Nizozemskoj također ima svaka osoba čiji pravni interes može biti povrijeđen odlukom tijela lokalne samouprave, ali i tijela koja u konkretnom slučaju štite javni interes. Vidi Van Haaren-Dresens, Ine, „Local government in Netherlands", Local government in the Member States of the European Union: a comparative legal perspective, National institute for public administration, Madrid, 2012., str. 477. 
postupku ispituje zakonitost osporenog rješenja, a ako je rješenje doneseno po slobodnoj ocjeni, ocjenjuje se i svrhovitost ovoga rješenja. ${ }^{68}$

Rok za podnošenje žalbe propisuje se zakonom te prije njegova isteka rješenje ne može postati pravomoćno. S druge strane, riječ je o prekluzivnom roku, što znači da u slučaju njegova propuštanja stranka gubi pravo na podnošenje žalbe.$^{69}$ Ako prvostupanjsko tijelo utvrdi da je žalba dopuštena, pravodobna i izjavljena od ovlaštene osobe, samo može odlučiti o opstojnosti vlastitog rješenja koje se žalbom osporava. Stoga prvostupanjsko tijelo tada razmatra žalbene navode te ispituje zakonitost odnosno ocjenjuje svrhovitost rješenja koje se žalbom osporava, ali to čini samo u granicama zahtjeva iz žalbe. Po provedenom postupku po žalbi, prvostupanjsko tijelo ocjenjuje ima li pravnih razloga da upravnu stvar riješi u cijelosti ili djelomično drukčije negoli je to učinilo osporenim rješenjem. Ako utvrdi da ovi razlozi postoje, ocijenit će žalbu u cijelosti ili djelomično osnovanom te zamijeniti osporeno rješenje novim, pod uvjetom da ne dira u prava trećih osoba. No, ako prvostupanjsko tijelo po provedenom postupku po žalbi ocijeni da je upravna stvar pravilno riješena, ono ne donosi negativno rješenje kojem će utvrditi da žalba nije osnovana, već je tada obvezno žalbu sa svim spisima predmeta, uključujući i spise dopunjenog ispitnog postupka, dostaviti na rješavanje drugostupanjskom tijelu. ${ }^{70}$

Nadzirući rad prvostupanjskog tijela prilikom rješavanja upravne stvari, drugostupanjsko tijelo ispituje zakonitost i ocjenjuje svrhovitosti osporenog rješenja. Pri razmatranju žalbe, drugostupanjsko tijelo vezano je granicama zahtjeva iz žalbe, ali ne i žalbenim razlozima. To znači da drugostupanjsko tijelo ispituje zakonitost i ocjenjuje svrhovitost samo onih dijelova rješenja koji se žalbom osporavaju, no nezakonitost ili nesvrhovitost može utvrditi iz razloga na koje žalitelj ukazuje, ali i iz drugih razloga. Međutim, u postupanju po žalbi drugostupanjsko tijelo je po službenoj dužnosti obvezno paziti na nadležnost $\mathrm{i}$ postojanje razloga za oglašivanje takvog rješenja ništavim. U odlučivanju po žalbi drugostupanjsko tijelo ima vrlo široke nadzorne ovlasti. Ono može žalbu odbiti, što će učiniti ako utvrdi da je neosnovana, ili je usvojiti, ako utvrdi da je osnovana. ${ }^{71}$ Ako žalbu usvoji, drugostupanjsko tijelo može rješenje poništiti u cijelosti ili djelomično, pri čemu koristi samo kasacijske ovlasti, ili ga izmijeniti, u kojem slučaju koristi ovlast meritornoga odlučivanja. Poništavanjem rješenja drugostupanjsko tijelo stavlja izvan snage osporeno rješenje i sve pravne učinke koje je ono proizvelo od trenutka kada je počelo važiti. ${ }^{72}$

68 Đerđa, op. cit., str. 246-247.

69 Člankom 109. Zakona o općem upravnom postupku propisan je opći rok za izjavljivanje žalbe u trajanju od 15 dana od dana dostave rješenja. No, ujedno je otvorena mogućnost da se posebnim zakonima propiše i duži rok.

70 C̆lanak 113., stavci 5. i 6 . Zakona o općem upravnom postupku. Isto rješenje u usporednom pravu susreće se npr. u Češkoj.

${ }^{71}$ Odbacivanje žalbe jest postupovna odluka pri donošenju koje se ne razmatra rješavanje upravne stvari.

72 Članak 115. Zakona o općem upravnom postupku. U postupanju po žalbi ovlast poništavanja 
Hijerarhijski nadzor zakonitosti pojedinačnih odluka koji nad izvršnim i upravnim tijelima lokalne samouprave provode tijela područne (regionalne) samouprave do izražaja dolazi i u primjeni izvanrednih pravnih lijekova u upravnome postupku. Tako, primjerice, rješenje može oglasiti ništavim tijelo koje obavlja nadzor nad tijelom koje ga je donijelo, što znači i drugostupanjsko tijelo, po službenoj dužnosti ili na prijedlog stranke u svako doba. Drugostupanjsko tijelo može također koristiti i izvanredni pravni lijek poništavanja i ukidanja rješenja, a ako takvoga tijela nema, rješenje može poništiti ili ukinuti tijelo koje na temelju zakona obavlja nadzor nad tijelom koje je izdalo prvostupanjski akt. ${ }^{73}$

Pored hijerarhijskog nadzora koji nad izvršnim i upravnim tijelima lokalne samouprave provode tijela jedinica područne (regionalne) samouprave, postoje i drugi oblici usustavljenoga upravnoga nadzora koji nad tim tijelima provode središnja državna tijela. Ovdje se kao posebno važni ističu upravni i inspekcijski nadzor koji nad tijelima jedinica lokalne samouprave obavlja Ministarstvo uprave koje je Zakonom o ustrojstvu i djelokrugu ministarstava i drugih središnjih tijela državne uprave određeno kao resorno središnje tijelo državne uprave za to upravno područje. ${ }^{74}$ Zadaća je ovoga Ministarstva voditi brigu o unapređenju upravnog postupanja i poslovanja općenito te pružati nadziranim tijelima stručnu pomoć kako se pogreške u budućnosti više ne bi ponavljale. Za obavljanje tih nadzornih poslova u Ministarstvu uprave ustrojeni su Služba za nadzor lokalne i područne (regionalne) samouprave, koja djeluje u sastavu Sektora za lokalnu i područnu (regionalnu) samoupravu Uprave za politički sustav, državnu upravu te lokalnu i područnu (regionalnu) samoupravu, te Sektor za inspekciju lokalne i područne (regionalne) samouprave, koji djeluje u sastavu Upravne inspekcije, a koja je ustrojena kao uprava u Ministarstvu. ${ }^{75}$

Služba za nadzor lokalne i područne (regionalne) samouprave obavlja upravne i stručne poslove koji se odnose na provedbu upravnog nadzora nad primjenom zakona i drugih propisa u području sustava i ustrojstva lokalne i područne (regionalne) samouprave, provodi nadzor zakonitosti općih akata i načina rada tijela jedinica lokalne i područne (regionalne) samouprave, prati rezultate izbora članova predstavničkih tijela i izvršnih tijela, provodi nadzor nad konstituiranjem predstavničkih tijela i njihovim djelovanjem kao i djelovanjem izvršnih tijela, prati nastupanje uvjeta za raspuštanje predstavničkih tijela, imenovanje povjerenika Vlade Republike Hrvatske te za raspisivanje prijevremenih izbora, daje stručna mišljenja o pitanjima provedbe propisa, vodi evidencije o podacima potrebnima

nezakonitih pojedinačnih odluka tijela lokalne samouprave susreće se npr. u Austriji, Nizozemskoj i Poljskoj. Vidi Gamper, op. cit., str. 39., Van Haaren-Dresens, op. cit., str. 478. i Kulesza, op. cit., str. 500.

73 Članak 128., stavak 2. i članak 131., stavak 1. Zakona o općem upravnom postupku.

74 Članak 10., stavak 1. Zakona o ustrojstvu i djelokrugu ministarstava i drugih središnjih tijela državne uprave.

75 Uredba o unutarnjem ustrojstvu Ministarstva uprave, Narodne novine, br. 28/12. i 65/15. Ustrojstvo, poslovi, način rada, prava i dužnosti upravne inspekcije uređeni su Zakonom o upravnoj inspekciji, Narodne novine, br. 63/08. 
Dr. sc. Dario Đerđa i dr. sc. Teodor Antić: Nadzor nad radom izvršnih i upravnih tijela jedinica... Zbornik radova Pravnog fakulteta u Splitu, god. 53, 1/2016., str. 165.-205.

za rad Službe, izrađuje izvješća, analize, stručna mišljenja i druge akte te obavlja i druge poslove u okviru svojega djelokruga. ${ }^{76}$

Međutim, s obzirom na ovlasti kojima ova Služba raspolaže na temelju mjerodavnih propisa, može se zaključiti kako je nadzor koji ta služba provodi u odnosu na samoupravni djelokrug uglavnom usmjeren prema predstavničkom tijelu jedinice lokalne samouprave, znatno manje prema izvršnom tijelu, a praktično se ne proteže i na nadzor rada upravnih tijela jedinice lokalne samouprave. ${ }^{77}$ Ovlasti kojima u provedbi upravnog nadzora raspolaže Ministarstvo uprave u prvome redu ovise o predmetu nadzora te se sastoje ili u donošenju određenih odluka ili u predlaganju Vladi poduzimanja određenih postupaka odnosno mjera iz njezine nadležnosti, kao što su raspuštanje predstavničkog tijela, imenovanje povjerenika, raspisivanje izbora i sl.

Inspekcijski je nadzor specijalizirani upravni nadzor koji se sastoji u neposrednom uvidu u poslovanje i postupanje određenih subjekata, uz poduzimanje odgovarajućih propisanih mjera. Predmet inspekcijskog nadzora jesu njihove neautoritativne aktivnosti u pogledu kojih se ispituje pridržavanje zakona, drugih propisa i općih akata. ${ }^{78} \mathrm{U}$ tom smislu, Sektor za inspekciju lokalne i područne (regionalne) samouprave obavlja poslove upravne inspekcije u primjeni zakona i drugih propisa o ustrojstvu, djelokrugu i načinu rada tijela jedinica lokalne samouprave i jedinica područne (regionalne) samouprave, provodi nadzor u provedbi zakona i drugih propisa o službenicima i namještenicima u tijelima jedinica lokalne i područne (regionalne) samouprave te provodi nadzor u provedbi općeg upravnog postupka, posebnih upravnih postupaka kao i uredskog poslovanja u tijelima jedinica lokalne i područne (regionalne) samouprave, a po potrebi provodi inspekcijski nadzor i u tijelima državne uprave, drugim državnim

76 Članak 10. Uredbe o unutarnjem ustrojstvu Ministarstva uprave.

77 S obzirom na predmet nadzora, Služba za nadzor lokalne i područne (regionalne) samouprave pretežno provodi nadzor zakonitosti rada predstavničkog tijela i nadzor općih akata koje donosi predstavničko tijelo.

78 Tomić, Zoran R., „Upravno pravo - sistem“, Službeni list SFRJ, Beograd, 2002. str 261. Dok je u teoriji upravnog prava više prihvaćen stav o inspekcijskom nadzoru kao jednom od oblika upravnog nadzora (primjerice: Borković, Upravno ..., op. cit., str. 238., Krijan, Pero, „Javne ovlasti kao poseban oblik javne vlasti“", Informator, god. 54. br. 5461-5462., 2006., male stranice, str. 5.), praksa prilično kategorički zastupa stav o dvije različite vrste nadzora. No čak i autori koji inspekcijski nadzor smatraju posebnom vrstom nadzora ističu kako su upravni i inspekcijski nadzor po sadržaju i metodama rada jednaki (primjerice: Gatarić, Đuro, Transformacija državne uprave, Pravni fakultet u Zagrebu, Zagreb Čakovec, 1984., str. 53.). Razlike koje se navode u prilog stajalištu o dvije različite vrste nadzora odnose se na službenike koji obavljaju nadzor (upravni nadzor načelno može obavljati svaki službenik koji za to dobije ovlaštenje, a inspekcijski nadzor mogu obavljati samo inspektori), na njihova prava, obveze i odgovornosti (inspektori imaju posebne obveze i odgovornosti iz kojih proizlaze i određena posebna prava iz službe kao što je primjerice dodatak na plaću), na ovlasti nadzornog tijela (kod upravnog nadzora, nadzorno tijelo pod određenim uvjetima ima obvezu izvršiti poslove umjesto nadziranog tijela kad ono to nije učinilo, dok inspekcije nemaju takve obveze) i na krug nadziranih subjekata (inspekcijski nadzor obavlja se nad puno širim krugom subjekata - njemu su potencijalno podložne sve fizičke i pravne osobe dok je upravni nadzor usmjeren na upravu u najširem smislu riječi - tijela uprave i lokalne samouprave te druge subjekte s javnim ovlastima). Rems, Vladimir, „Inspekcijski nadzor nad tijelima javne vlasti te nad fizičkim i pravnim osobama u zakonodavstvu Republike Hrvatske“, Hrvatska pravna revija, god. 8., br. 2., 2008., str. 64-66.; Gatarić, op. cit., str. 53. 
Dr. sc. Dario Đerđa i dr. sc. Teodor Antić: Nadzor nad radom izvršnih i upravnih tijela jedinica... Zbornik radova Pravnog fakulteta u Splitu, god. 53, 1/2016., str. 165.-205.

tijelima i pravnim osobama s javnim ovlastima, sudjeluje s drugim ustrojstvenim jedinicama u provedbi upravnog nadzora te obavlja i druge upravne i stručne poslove koji su posebnim zakonima i drugim propisima stavljeni u djelokrug Upravne inspekcije. ${ }^{79}$

Inspekcijski nadzor Upravna inspekcija provodi neposredno ili posredno. Neposrednim inspekcijskim nadzorom smatra se izravni uvid u opće i pojedinačne akte u nadziranom tijelu, kao i u uvjete i način rada nadziranog tijela, dok se posrednim inspekcijskim nadzorom smatra izravni uvid u dostavljene podatke i dokumentaciju. ${ }^{80}$ Ukoliko nakon provedenoga inspekcijskog nadzora utvrdi nezakonitosti, nepravilnosti i/ili nedostatke u radu nadziranog tijela, upravni inspektor sastavlja zapisnik u kojem može izreći određene mjere, izdati određene naredbe i zabrane te predložiti određene postupke s ciljem otklanjanja utvrđenih nezakonitosti ili unapređenja rada nadziranog tijela.

Osim po službenoj dužnosti, upravna inspekcija postupa i po predstavkama na rad tijela jedinica lokalne i područne (regionalne) samouprave. Ukoliko navode iznesene u predstavci upravni inspektor ocijeni osnovanima, ovlašten je uputiti upozorenje radi hitnog uklanjanja mogućih nezakonitosti. Ako otklanjanje nezakonitosti ili nepravilnosti zahtijeva izricanje mjere, upravni inspektor po službenoj dužnosti provodi inspekcijski nadzor. Upravni inspektor dužan je obavijestiti podnositelja predstavke o utvrđenim činjenicama odnosno poduzetim mjerama povodom predstavke.

Dakle, ovlasti kojima raspolaže Ministarstvo uprave u prvome redu ovise o predmetu nadzora te se sastoje ili u donošenju određenih odluka ili u predlaganju Vladi poduzimanja određenih postupaka odnosno mjera iz njezine nadležnosti. Nadzorne ovlasti u ovome mehanizmu nadzora nisu pretjerano represivne te ne uključuju ni objektivno stavljanje izvan snage niti meritorno rješavanje, a koje ovlasti su tipične za hijerarhijski nadzor. Ovlasti kojima raspolažu tijela koja provode upravni i inspekcijski nadzor u bitnome se svode na konstataciju nezakonitosti te na davanje preporuka i uputa nadziranim tijelima o načinu ispravljanja ${ }^{81}$ Iako je u navedenim ustrojstvenim jedinicama Ministarstva uprave

79 Članak 46. Uredbe o unutarnjem ustrojstvu Ministarstva uprave.

80 Propisi koje primjenjuju tijela lokalne i područne (regionalne) samouprave, a nad čijom primjenom Upravna inspekcija provodi nadzor, mogu se razvrstati u četiri grupe: propisi kojima se uređuje sustav lokalne i područne (regionalne) samouprave, propisi kojima se uređuju službenički odnosi u tijelima jedinica lokalne i područne (regionalne) samouprave, propisi kojima se uređuje opći upravni postupak i posebni upravni postupci koje provode tijela jedinica lokalne i područne (regionalne) samouprave i ostali posebni propisi, kao npr. propisi o uredskom poslovanju, o pravu na pristup informacijama, o sadržaju naziva tijela jedinica lokalne i područne (regionalne) samouprave te uporabu propisanih obilježja i simbola, o pečatima i žigovima s grbom Republike Hrvatske i dr.

81 U Austriji su uspostavljeni različiti mehanizmi upravnoga nadzora. Tako primjerice nadzorno tijelo može od tijela jedinice lokalne samouprave zatražiti podatke o svakom postupku koji je ovo tijelo provelo. Jedinice lokalne samouprave obvezne su dostaviti nadzornom tijelu sve tražene podatke te mu omogućiti provedbu nadzora. Međutim, pri korištenju nadzornih ovlasti, nadzorna tijela posebnu pozornost moraju voditi o stečenim pravima trećih osoba. Specifičan oblik upravnog nadzora ustrojen je u Danskoj. Ovdje upravni nadzor nad radom izvršnih i upravnih tijela jedinica lokalne samouprave provode uredi državne uprave u regijama. U slučaju utvrđivanja nezakonitosti u radu tijela lokalne samouprave nadzorna tijela 
Dr. sc. Dario Đerđa i dr. sc. Teodor Antić: Nadzor nad radom izvršnih i upravnih tijela jedinica... Zbornik radova Pravnog fakulteta u Splitu, god. 53, 1/2016., str. 165.-205.

predviđeno sedam odnosno osam službenika i namještenika, u Službi za nadzor lokalne i područne (regionalne) samouprave stvarno su popunjena samo dva, a u Sektoru za inspekciju lokalne i područne (regionalne) samouprave stvarno su popunjena samo četiri radna mjesta. S obzirom na broj zaposlenika koji obavljaju ovaj oblik nadzora nad jedinicama lokalne samouprave te na 556 općina i gradova te 20 županija nad kojima se nadzor provodi, postavlja se pitanje može li on u praksi uopće biti djelotvoran. Kad se tome pridoda činjenica da u sustavu postoji velik broj jedinica lokalne samouprave koje zbog svoje veličine objektivno imaju problema s kadrovskim, materijalnim, financijskim potencijalima što nedvojbeno utječe na mogućnost i pravilnost obavljanja njihovih zadaća, na to pitanje teško je očekivati pozitivan odgovor. ${ }^{82}$

Na temelju prethodnih razmatranja, općenito se može zaključiti kako upravni nadzor nad izvršnim i upravnim tijelima lokalne samouprave treba biti ustrojen ponajprije na način da se u njegovoj provedbi respektiraju i zaštite samoupravne ovlasti lokalne samouprave, a da se pritom istodobno zaštiti zakonitost u

kao najblažu mjeru koriste pisano izvješće u kojemu utvrđuju počinjenu povredu te daju preporuku za njezino uklanjanje. Tijela jedinica lokalne samouprave u pravilu postupaju prema preporukama iz izvješća, jer u protivnom ured može poništiti nezakonitu pojedinačnu odluku. No, valja naglasiti kako ured nema ovlast i meritorno riješiti upravni predmet. Slično, upravni nadzor nad zakonitošću odluka izvršnih tijela jedinica lokalne samouprave u Francuskoj obavlja prefekt, kao čelnik područne jedinice lokalne samouprave. Međutim, u slučaju utvrđene nezakonitosti, on nema nikakve represivne ovlasti, već samo može od tijela jedinice lokalne samouprave zatražiti da izmijeni pojedinačnu odluku, a ako ono to odbije, prefekt takvu odluku jedino može osporavati tužbom pred upravnim sudom. Sličan slučaj susreće se i u Mađarskoj gdje tijela regionalne samouprave nadziru rad izvršnih i upravnih tijela lokalne samouprave. Niti ova tijela nemaju ovlast poništiti nezakonitu pojedinačnu odluku, već samo mogu pozvati nadležna tijela da to učine te im u tu svrhu odrediti primjereni rok. No, ako tijela lokalne samouprave ne izmijene takve akte, nadzorno tijelo također može jedino pokrenuti sudski postupak kako bi takva odluka bila poništena. Posebno ustrojena tijela, tzv. specijalne nadzorne službe obavljaju nadzor nad radom izvršnih i upravnih tijela jedinica lokalne samouprave i u Grčkoj. Ovim službama rukovode tzv. nadzornici zakonitosti. U ovim službama zapošljavaju se isključivo osobe sa završenom visokom stručnom spremom pravnog, ekonomskog i tehničkog smjera, kako bi se osigurala najkvalitetnija moguća razina nadzora. Ova služba ovlaštena je stavljati izvan snage nezakonite odluke jedinica lokalne samouprave. S druge strane, u Nizozemskoj postoji i sustav upravnoga nadzora u kojemu viša tijela nadziru rad tijela jedinica lokalne samouprave, i to kako njihovu zakonitost, tako i učinkovitost i pravovremenost. Nezakonite $\mathrm{i}$ nepravilne odluke nadzorna tijela mogu staviti izvan snage. Pozivajući se na zaštitu javnoga interesa, ova tijela značajno mogu utjecati na politike lokalne samouprave. Gamper, Anna, op. cit., str. 39., Greve, Emil, op. cit., str. 151., Szente, Zoltan, op. cit., str. 304., Hlepans, Nikolaos-Komninos, op. cit., str. 278. Van Haaren-Dresens, Ine, op. cit. str. 478. te Hertzog, Robert, „Local government in France“, Local government in the Member States of the European Union: a comparative legal perspective, National institute for public administration, Madrid, 2012., str. 227.

82 Na ovo upućuje podatak da je u 2014. godini inspekcijskim nadzorom bilo obuhvaćeno tek 15 jedinica lokalne samouprave, što čini tek $2,7 \%$, a pri čemu je izrečeno ukupno 588 različitih mjera, u prosjeku 37 po svakoj jedinici. Pritom je najveći dio povrede vezan uz opće akte i službeničke odnose. To je nedvojbeno razmjerno velik broj nezakonitosti i nepravilnosti u radu njihovih tijela pa ako se po tom uzorku može ocijeniti zakonitost i pravilnost rada lokalne samouprave općenito, ona bi teško mogla biti zadovoljavajuća. Razlozi nedovoljne djelotvornosti inspekcijskog nadzora mogu se naći u nedostatku upravnih inspektora i nemogućnosti zapošljavanja novih inspektora, prije svega zbog nerazmjera složenosti poslova i odgovornosti upravnih inspektora s jedne strane te vrlo malih koeficijenata za obračun plaća upravnih inspektora s druge strane, a koji koeficijenti su znatno manji od koeficijenata propisanih za druga radna mjesta približne složenosti poslova i odgovornosti, npr. službenika Državne revizije, službenika Ministarstva financija - Proračunskog nadzora, savjetnika Pučkog pravobranitelja i sl. Vidi godišnja izvješća o radu Ministarstva uprave za 2012., 2013. i 2014. godinu, dostupno na: https://uprava. gov.hr/pristup- informacijama/strategije-planovi-i-izvješća/izvješća/1055, pristup: 9. lipnja 2015. 
cjelokupnom pravnom sustavu. Vrlo snažno sredstvo ovoga nadzora predstavlja hijerarhijski nadzor koji se provodi u žalbenom postupku od strane tijela jedinica područne (regionalne) samouprave. Treba voditi računa da drugi oblici nadzora, koji uključuju nadzornu aktivnost središnjih državnih tijela, ne podjeljuju one restriktivne ovlasti nadzornim tijelima, kojima bi ona mogla ugroziti samoupravna prava jedinica lokalne samouprave.

\section{SUDSKI NADZOR NAD IZVRŠNIM I UPRAVNIM TIJELIMA LOKALNE SAMOUPRAVE}

Pored nadzorakoji se nadizvršnimiupravimtijelimajedinicalokalne samouprave ustrojava od njih samih ili drugih područnih (regionalnih) samoupravnih ili središnjih državnih tijela, ova tijela nadziru i nositelji koji djeluju izvan upravnog sustava. Tako se jednim od bitnih čimbenika kvalitetnoga funkcioniranja javne uprave uopće naglašava institut upravnog spora. Sudski nadzor pokazuje se najsnažnijim oblikom pravne zaštite uopće upravo zbog neovisnosti i autoriteta nositelja ovoga nadzora, a koji svoje odluke treba zasnivati isključivo na pravnim normama, ne upuštajući se u svrhovitost donošenja pojedine odluke. S gledišta pravne doktrine, upravo je sudski nadzor predstavljao najsavršeniji oblik nadzora nad zakonitošću akata upravnih tijela, odnosno djelovanja njihovih službenih osoba.$^{83}$ Stupanj u kojem je sudska zaštita zajamčena te koliko se učinkovito ona obavlja, ključni su element pri ocjeni svakog modernog pravnog sustava. ${ }^{84}$ Sudska presuda koja stavlja izvan snage nezakonit upravni akt ili nalaže državi da naknadi štetu oštećenom pojedincu, ne umanjuje učinkovitost i ugled javne uprave već, naprotiv, takva presuda doprinosi unapređenju njezine djelatnosti, štiti javnu vlast te stvara povjerenje građana u institucije države. ${ }^{85}$ Značajno obilježje ovoga mehanizma nadzora nad upravom jest pokretanje isključivo na osnovi zahtjeva za pružanjem pravne zaštite koji može podnijeti samo posebno legitimirana osoba te da je sudska odluka donesena u tom postupku načelno nepromjenjiva, sa snagom zakonske istine, odnosno sa svojstvom presuđene stvari. Sudski nadzor ujedno čini završni nadzor zakonitosti odluka i postupanja uprave.

Upravni spor u Hrvatskoj uređen je Zakonom o upravnim sporovima. Cilj je ovoga Zakona osigurati zakonitost i sudsku zaštitu prava i pravnih interesa fizičkih i pravnih osoba i drugih stranaka povrijeđenih pojedinačnim odlukama ili postupanjem javnopravnih tijela. Sudski nadzor zakonitosti rada izvršnih i

83 Borković, Upravno..., op. cit., str. 128. te 483. Slično tvrdi i Cardona, ističući da je „sudski nadzor najsnažnije jamstvo pojedinaca u njihovom ophođenju s upravom“. Cardona, Francisco, „Converging Judicial Control of the Administration in Europe“, Judicial Reform and Administrative Justice, SIGMA, 2005., str. 2.

84 Vidi u Kujundžić, Ivica, „Upravno sudstvo u Hrvatskoj i zemljama Europske unije“, Upravno pravo i upravni postupak u praksi - aktualna pitanja i problemi, Inženjerski biro, Zagreb, 2006., str. 7.

${ }^{85}$ Cardona, op. cit., str. 2. O značenju upravnog spora u zaštiti prava pojedinaca više vidi u Đerđa, Dario, „Upravni spor u Hrvatskoj: sadašnje stanje i pravci reforme“, Zbornik Pravnog fakulteta Sveučilišta u Rijeci, vol. 29., br. 1., 2008., str. 1-4. 
upravnih tijela jedinica lokalne samouprave utvrđen je i u Zakonu o lokalnoj i područnoj (regionalnoj) samoupravi koji propisuje kako se protiv odluke donesene u žalbenom postupku o zakonitosti i pravilnosti pojedinačnog akta upravnog tijela jedinice lokalne samouprave može pokrenuti upravni spor sukladno odredbama Zakona o upravnim sporovima. Dakle, u ovome slučaju upravni spor ne pokreće se protiv odluke jedinice lokalne samouprave, već protiv odluke jedinice područne (regionalne) samouprave koja je u drugom stupnju rješavala o zakonitosti i pravilnosti pojedinačne odluke upravnog tijela jedinice lokalne samouprave. Stoga je ovaj oblik sudskoga nadzora u upravnome sporu samo posredno usmjeren na rad upravnih tijela jedinica lokalne samouprave. Ujedno, Zakon o lokalnoj i područnoj (regionalnoj) samoupravi propisuje kako se upravni spor može pokrenuti izravno protiv pojedinačnih akata predstavničkog tijela i općinskog načelnika odnosno gradonačelnika, kojima se rješava o pravima, obvezama i pravnim interesima fizičkih i pravnih osoba, ako posebnim zakonom nije drukčije propisano, čime u izravni nadzor upravnih sudova stavlja ocjenu zakonitosti pojedinačnih akata koje donose izvršna, ali i predstavnička tijela jedinice lokalne samouprave. ${ }^{86}$

Upravni spor može se, dakle, pokrenuti s ciljem osporavanja zakonitosti pojedinačne odluke predstavničkog tijela i općinskog načelnika odnosno gradonačelnika kojima su ova tijela odlučila o pravu, obvezi ili pravnom interesu stranke u upravnoj stvari protiv koje nije dopušteno izjaviti redoviti pravni lijek, zatim osporavanja zakonitosti postupanja ovih tijela iz područja upravnog prava kada je takvim postupanjima povrijeđeno pravo, obveza ili pravni interes stranke protiv kojeg nije dopušteno izjaviti redoviti pravni lijek, osporavanja zakonitosti propuštanja ovih tijela iz područja upravnog prava da u zakonom propisanom roku odluče o pravu, obvezi ili pravnom interesu stranke odnosno da postupe prema propisu te, konačno, osporavanja zakonitosti sklapanja, raskidanja i izvršavanja upravnog ugovora. ${ }^{87}$ Predmet upravnog spora može biti i ocjena zakonitosti općeg akta jedinice lokalne i područne (regionalne) samouprave, kao i pravne osobe koja ima javnu ovlast i pravne osobe koja obavlja javnu službu, no kako takvi akti u pravilu nisu rezultat obavljanja izvršnih i upravnih aktivnosti, ovaj oblik nadzora u radu se detaljnije ne razmatra. Međutim, postoje i slučajevi koji su isključeni od vođenja upravnoga spora. Tako se ovaj spor ne može voditi u stvarima u kojima je sudska zaštita osigurana izvan upravnog spora, ne može se voditi o pravilnosti

86 Članak 76., stavak 5. te članak 77.a Zakona o lokalnoj i područnoj (regionalnoj) samoupravi.

87 Predmet upravnoga spora vrlo je široko postavljen u Francuskoj, gdje se upravni spor može voditi u svim upravnim područjima i protiv bilo kojega pojedinačnog i općega akta svakoga javnopravnoga tijela, bez obzira na to djeluje li takvo tijelo na središnjoj, regionalnoj odnosno lokalnoj razini ili su mu kao osobi privatnoga prava povjerene javne ovlasti. Upravni sporovi u Francuskoj ujedno se mogu voditi i o zakonitosti upravnih ugovora, kao i podzakonskih općih akata. O ovome vidi Braibant, Guy, „Administrativno pravo Francuske“, Službeni list Jugoslavije, Beograd, 2002., str. 375-376. Slično je i u Njemačkoj gdje se u upravnome sporu također mogu osporavati sve radnje javnopravnih tijela, dakle, kako pojedinačne odluke, tj. upravni akti, tako i druga postupanja, ali i propuštanja tijela da $u$ zakonom propisanom roku donesu odluku ili postupe. U Njemačkoj se u upravnom sporu može utvrđivati i postojanje ili nepostojanje nekog upravnopravnoga odnosa, kao i zakonitosti upravnoga ugovora ili izvršavanje obveze iz upravnoga ugovora. 
Dr. sc. Dario Đerđa i dr. sc. Teodor Antić: Nadzor nad radom izvršnih i upravnih tijela jedinica... Zbornik radova Pravnog fakulteta u Splitu, god. 53, 1/2016., str. 165.-205.

pojedinačne odluke donesene primjenom slobodne ocjene javnopravnog tijela niti se može voditi protiv postupovne odluke javnopravnog tijela. ${ }^{88}$

Upravni spor pokreće se tužbom koja se podnosi mjesno nadležnom prvostupanjskom upravnom sudu. ${ }^{89}$ Tužbu podnosi tužitelj, u kojem se položaju može naći svaka fizička ili pravna osoba koja smatra da su joj prava i pravni interesi povrijeđeni pojedinačnom odlukom, postupanjem javnopravnog tijela, odnosno propuštanjem donošenja pojedinačne odluke ili postupanja javnopravnog tijela u zakonom propisanom roku ili sklapanjem, raskidom ili izvršavanjem upravnog ugovora; osoba koja nema pravne osobnosti ili skupina osoba ako su pojedinačnom odlukom ili postupanjem javnopravnog tijela povrijeđena njihova prava i pravni interesi; javnopravno tijelo koje je sudjelovalo ili je trebalo sudjelovati u donošenju odluke, postupanju ili sklapanju upravnog ugovora; kao i drugo državno tijelo ovlašteno zakonom. ${ }^{90}$ Tužitelj tužbom može zahtijevati poništavanje ili oglašivanje ništavom pojedinačne odluke, donošenje pojedinačne odluke koja nije donesena u propisanom roku, postupanje koje je tuženik sukladno propisima ili pojedinačnoj odluci obvezan izvršiti te oglašivanje ništetnim upravnog ugovora ili izvršavanje obveze iz upravnog ugovora. Kada je tužitelj tužbom zahtijevao poništavanje ili oglašivanje ništavom pojedinačne odluke ili donošenje pojedinačne odluke koja nije donesena u propisanom roku, ujedno može zahtijevati da sud odluči o pravu, obvezi ili pravnom interesu stranke. Kao sporedni zahtjev u upravnom sporu, tužitelj još može postaviti i zahtjev za povratom stvari i/ili naknadom štete koju je počinilo tuženo tijelo lokalne samouprave. Tužba se podnosi u prekluzivnom roku od 30 dana od dostave osporene pojedinačne odluke ili odluke o prigovoru na osporeno postupanje. ${ }^{91}$

88 Članci 2., 3. i 4. Zakona o upravnim sporovima.

89 U Hrvatskoj je ustrojen sustav specijaliziranoga upravnoga sudovanja te se upravni sporovi vode pred posebno ustrojenim upravnim sudovima. Time je u Hrvatskoj usvojen tzv. francuski sustav upravnoga sudovanja koji je ujedno zastupljen u najvećem broju europskih država kao npr. u Austriji, Belgiji, Bugarskoj, Finskoj, Francuskoj, Grčkoj, Italiji, Letoniji, Njemačkoj, Poljskoj, Portugalu, Rumunjskoj, Švedskoj itd. Uz ovaj sustav postoji i tzv. sustav redovitih sudova, koji je povijesno vezan uz Ujedinjeno Kraljevstvo, odakle se prenio na Australiju, Cipar, Estoniju, Dansku, Indiju, Irsku, Izrael, Kanadu, Maltu, Norvešku, Novi Zeland, Sjedinjene Države i sl. U Hrvatskoj djeluju četiri prvostupanjska upravna suda: Upravni sud u Zagrebu, Upravni sud u Rijeci, Upravni sud u Splitu i Upravni sud u Osijeku, te drugostupanjski Visoki upravni sud Republike Hrvatske. Samo iznimno u prvome stupnju odlučuje Visoki upravni sud, kao npr. protiv rješenja povjerenika za informiranje te protiv odluka i drugih upravnih akata Hrvatske agencije za poštu i elektroničke komunikacije. Vidi članak 26. Zakona o pravu na pristup informacijama, Narodne novine, br. 25/13. te članak 18. stavak 2. Zakona o elektroničkim komunikacijama, Narodne novine, br. 73/08., 90/11., 133/12. i 80/13.

90 Članak 17. Zakona o upravnim sporovima. Koje će državno tijelo biti ovlašteno podnijeti tužbu ovisi o zakonima kojima se uređuje nadležnost pojedinih tijela, kao što su primjerice zakoni kojima se uređuje nadležnost državnog odvjetništva, pučkog pravobranitelja, drugih pravobranitelja itd., ili zakonima kojima se uređuje neko posebno upravno područje. Cilj podnošenja tužbe od državnih tijela ovlaštenih zakonom jest očuvanje objektivne zakonitosti u društvenoj zajednici, tj. pokretanje spora kada je nekoj osobi nezakonito priznato neko pravo koje joj ne pripada ili joj nije određena neka obveza koja joj se prema propisima trebala odrediti. Šroka legitimacija tužitelja u upravnom sporu susreće se i u Poljskoj, gdje tužbu upravnom sudu može podnijeti svaka osoba kojoj su prava i pravni interesi povrijeđeni pojedinačnom odlukom tijela jedinice lokalne samouprave. Vidi Kulesza, op. cit., str. 501.

91 Članak 22., stavci 2. do 4. i članak 24., stavak 1. Zakona o upravnim sporovima. Rokovi za podnošenje tužbe u upravnom sporu prilično su različiti. Tako se, primjerice, tužba može podnijeti u roku 
Dr. sc. Dario Đerđa i dr. sc. Teodor Antić: Nadzor nad radom izvršnih i upravnih tijela jedinica... Zbornik radova Pravnog fakulteta u Splitu, god. 53, 1/2016., str. 165.-205.

U upravnome sporu Sud odlučuje u granicama tužbenog zahtjeva, ali nije vezan razlozima tužbe. Jedino na razloge ništavosti pojedinačne odluke i ništetnosti upravnog ugovora sud pazi po službenoj dužnosti. ${ }^{92}$ U slučaju neosnovanosti tužbenoga zahtjeva, sud će takav zahtjev odbiti. No, ako utvrdi da je tužbeni zahtjev osnovan, sud pobijanu odluku poništava ili oglašava ništavom te sam rješava stvar, osim kada to ne može učiniti s obzirom na prirodu stvari ili zato što je tuženik rješavao po slobodnoj ocjeni. Ako utvrdi da tuženik nije postupio sukladno propisima, pojedinačnoj odluci ili upravnom ugovoru, naredit će mu postupanje u primjerenom roku. ${ }^{93}$ Time sud raspolaže širokim nadzornim ovlastima: i ovlašću objektivnoga stavljanja izvan snage i ovlašću meritornoga rješavanja, ovisno o tome rješava li upravni spor kao spor o zakonitosti ili spor pune jurisdikcije. ${ }^{94}$ Sudska odluka donesena od prvostupanjskoga suda može se dalje osporavati u žalbenom postupku, ali i izvanrednim pravnim lijekovima, tj. obnovom spora i zahtjevom za izvanredno preispitivanje zakonitosti pravomoćne presude. $^{95}$

Sudska zaštita čini se izuzetno važnom u području lokalne samouprave, jer kada tijelo jedinice područne (regionalne) samouprave u žalbenom postupku meritorno rješava o upravnoj stari o kojoj je u prvom stupnju odlučivalo upravno tijelo jedinice lokalne samouprave, ali i kada središnja državna vlast provodi bilo kakav oblik upravnoga nadzora nad pojedinačnim odlukama i postupanjima lokalne samouprave, upravo sudska zaštita treba zajamčiti pravilnu provedbu pravnih normi, bez obzira na državne, područne (regionalne) ili lokalne interese koji nezakonito mogu utjecati na prava i pravne interese pojedinaca. Konačno, valja naglasiti kako je nadzor koji se provodi u upravnom sporu samo jedan od segmenata sudskoga nadzora nad radom javne uprave jer, primjerice, županijski i općinski sudovi imaju važnu ulogu u utvrđivanju kaznene odgovornosti ovih osoba ili odlučivanja o iznosu naknade štete nanesene pojedincima nezakonitim radom službenika zaposlenih u ovim tijelima. ${ }^{96}$

od 30 dana u Finskoj, Poljskoj i Letoniji, u roku od jednog mjeseca u Njemačkoj, u roku od šest tjedana u Austriji, u roku od 60 dana u Italiji, a u roku od dva mjeseca u Francuskoj, Španjolskoj i Češkoj. U Irskoj i Ujedinjenom Kraljevstvu ovaj je rok tri mjeseca, a u Belgiji čak šest mjeseci.

92 Članak 31. Zakona o upravnim sporovima. U Austriji npr. Upravni sud također može odlučivati samo u okviru tužbenog zahtjeva te ne smije po službenoj dužnosti premašiti granice koje je tužitelj postavio u tužbi. Granicama tužbenog zahtjeva upravni sudovi vezani su i u Francuskoj, osim kada utvrde da je odluku donijelo nenadležno tijelo ili da je prilikom odlučivanja javnopravno tijelo prekoračilo zakonom propisane ovlasti. Upravni sudovi vezani su tužbenim zahtjevom i u Njemačkoj, no ovdje nisu vezani razlozima iznesenima u tužbi, pa nezakonitost mogu utvrditi i iz kojega drugog razloga.

93 Članak 58. Zakona o upravnim sporovima.

94 Današnja praksa u pojedinim državama pokazuje da se u nekim državama velik broj upravnih sporova rješava kao spor pune jurisdikcije, primjerice u Francuskoj ili Njemačkoj. U drugim državama upravni sporovi primarno se rješavaju kao sporovi o zakonitosti, dok su sporovi pune jurisdikcije pravi izuzetak, kao primjerice u Austriji.

95 Vidi članke 66. do 78. Zakona o upravnim sporovima.

96 Krbek, Pravo..., op. cit., str. 81. 


\section{NADZOR PUČKOGA PRAVOBRANITELJA NAD IZVRŠNIM I UPRAVNIM TIJELIMA LOKALNE SAMOUPRAVE}

Konačno, stanoviti oblik nadzora nad izvršnim i upravnim tijelima jedinica lokalne samouprave, iako s prilično slabim nadzornim ovlastima, obavlja pučki pravobranitelj. Pučki pravobranitelj, odnosno parlamentarni ombudsman, kako se često još naziva, povjerenik je parlamenta koji ispituje utemeljenost predstavki pojedinaca na određene nezakonitosti, odnosno nepravilnosti postupanja upravnih tijela i službenika zaposlenih u tim tijelima. ${ }^{97}$ Stoga je ova osoba izuzetno važna u obavljanju nadzora nad radom uprave općenito, pa tako i izvršnih i upravnih tijela jedinica lokalne samouprave. Pučkoga pravobranitelja obilježavaju tri bitna svojstva: povjerenik je parlamenta, uspostavljen u pravilu ustavom ili zakonom, funkcionalno neovisan o svim drugim funkcijama u državi; zadatak mu je na relativno neformalan način ispitivati slučajeve povreda prava pojedinaca do kojih je došlo nezakonitim i nepravilnim radom upravnih tijela; te je ovlašten konstatirati uočenu nezakonitost ili nepravilnost rada tijela nad kojima je ovlašten obavljati nadzor, kao i davati prijedloge i preporuke u svezi s mjerama koje treba poduzeti kako bi se uočena nezakonitost ili nepravilnost otklonila. ${ }^{98}$ Međutim, pučki pravobranitelj nema ovlast staviti nezakonit ili nepravilan akt izvan snage, baš kao što nema niti ovlast meritorno riješiti upravnu stvar.

Pučkije pravobranitelju Hrvatskojustanovljen 1990. godine. ${ }^{99}$ Ustrojidjelovanje pučkoga pravobranitelja uređeno je Zakonom o pučkom pravobranitelju. ${ }^{100}$ Ovim Zakonom pučki pravobranitelj utvrđen je kao opunomoćenik Hrvatskoga sabora za promicanje i zaštitu ljudskih prava i sloboda utvrđenih Ustavom, zakonima i međunarodnim pravnim aktima o ljudskim pravima i slobodama koje je prihvatila Republika Hrvatska. Zadaća mu je u prvom redu promicati i štititi ljudska prava i slobode te vladavinu prava, razmatrajući pritužbe o postojanju nezakonitosti i nepravilnosti u radu državnih tijela, tijela jedinica lokalne i područne (regionalne) samouprave i pravnih osoba s javnim ovlastima. ${ }^{101}$ Izuzetno važna

97 Pučki pravobranitelj kao institut uveden je prvi put u Švedskoj 1810. godine te je ubrzo 1919. godine ustanovljen i u Finskoj. Ovaj institut zatim je uveden i u Norveškoj 1952. godine, Danskoj 1953. godine, Njemačkoj 1956. godine, U Francuskoj 1973. godine, Portugalu 1976. godine, Austriji 1977. godine itd. Aviani, op. cit., str. 57-70.

98 Aviani, op. cit., str. 192.

99 Pored pučkoga pravobranitelja s općim nadležnostima, u Hrvatskoj još djeluju pravobranitelj za djecu, pravobranitelj za osobe s invaliditetom i pravobranitelj za ravnopravnost spolova. U Belgiji i Italiji svaka jedinica lokalne samouprave ima ovlast ustrojiti vlastitoga pučkog pravobranitelja koji će postupati po pritužbama građana na nezakonito i nepravilno postupanje tijela te jedinice. Vidi Bouvier, op. cit., str. 61., Vandelli, op. cit., str. 360.

100 Zakon o pučkom pravobranitelju, Narodne novine, br. 76/12.

101 Članak 2., stavak 1. i članak 4. Zakona o pučkom pravobranitelju. Zadaća je švedskog pučkog pravobranitelja kontrolirati primjenu zakona i drugih propisa od strane onih subjekata koji obavljaju javne poslove, tj. nadzirati izvršavaju li ovi subjekti pravilno svoje poslove. U tom je smislu predmet nadzora švedskog pučkog pravobranitelja zakonitost i pravilnost rada onih subjekata koji obavljaju javne poslove. Pučki pravobranitelj u Finskoj nadzire poštovanje prava u funkcioniranju sudova i drugih tijela vlasti, pri čemu je njegov rad primarno usmjeren na ocjenu zakonitosti. S druge strane, danski pučki pravobranitelj nadzire državnu i vojnu upravu na način da ocjenjuje primjenjuje li pogrešno pravo, donosi arbitrarne ili 
ovlast pučkoga pravobranitelja u obavljanju nadzora nad jedinicama lokalne samouprave svakako je davanje preporuka, mišljenja, prijedloga i upozorenja ovim tijelima u slučaju nezakonitoga postupanja. Svaka osoba koja smatra da su nezakonitim ili nepravilnim radom tijela lokalne samouprave ugrožena ili povrijeđena njezina ustavna ili zakonska prava i slobode, može podnijeti pritužbu pučkom pravobranitelju radi pokretanja postupka. Pučki pravobranitelj slobodno odlučuje hoće li pritužbu uzeti u razmatranje i u kojem opsegu. Međutim, pučki pravobranitelj radi ispitivanja pojedinačnih ili učestalih istovrsnih povreda ustavnih ili zakonskih prava i sloboda može pokrenuti postupak i na vlastitu inicijativu. Ipak, on ne postupa u slučajevima o kojima se vodi sudski postupak, osim ako se radi o nepotrebnom odugovlačenju postupka ili očitoj zloupotrebi ovlasti. ${ }^{102}$

Pučki pravobranitelj razmotrit će pritužbu bez provođenja ispitnoga postupka kad se iz činjenica navedenih u pritužbi i općepoznatih činjenica odnosno službenih podataka kojima raspolaže nedvojbeno može utvrditi jesu li podnositelju ugrožena ili povrijeđena ustavna ili zakonska prava. U slučaju kad pučki pravobranitelj provodi ispitni postupak, ovlašten je zatražiti potrebne informacije, podatke, objašnjenja, akte i drugu dokumentaciju od tijela jedinice lokalne samouprave. Po provedenom postupku, izrađuje izvješće o tome slučaju, koje dostavlja tijelu na čiji se rad pritužba odnosi te podnositelju pritužbe. Ovo izvješće obvezno treba sadržavati opis činjenica i okolnosti razmatranog slučaja, ocjenu o tome jesu li ugrožena ili povrijeđena ustavna ili zakonska prava podnositelja te na koji način je ugrožavanje ili povreda prava učinjena. Pučki pravobranitelj u izvješću o slučaju, kada god je to moguće, preporučuje ili predlože način na koji se ugrožavanje ili povreda prava može otkloniti. Ako u obavljanju dužnosti utvrdi da su povrijeđena prava podnositelja pritužbe s elementima kaznenog djela, prekršaja ili povrede radne discipline, može čak predložiti i pokretanje kaznenog, prekršajnog ili disciplinskog postupka. Tijela jedinica lokalne samouprave dužna su obavijestiti pučkog pravobranitelja, u roku koji im odredi, o mjerama poduzetima povodom njegove preporuke ili prijedloga. ${ }^{103}$

Važna ovlast pučkoga pravobranitelja u obavljanju nadzora nad jedinicama lokalne samouprave svakako je i podnošenje redovitih godišnjih izvješća Hrvatskome saboru. Ova izvješća sadrže analizu i ocjenu stanja zaštite prava i sloboda u Republici Hrvatskoj, analizu i ocjenu stanja vezanu za određene pojavne oblike povreda prava pojedinaca ili pojedinih društvenih skupina, ocjenu o mjeri u kojoj su nadzirana tijela postupala u skladu s prethodnim

nerazborite odluke, nemarno obavlja svoju dužnost ili na drugi način čini greške u radu. Konačno, zadaća je norveškog pučkog pravobranitelja voditi računa da javna uprava građaninu ne učini određenu nepravdu. Vidi Aviani, op. cit., str. 103-110.

102 Članci 15. do 18. Zakona o pučkom pravobranitelju.

103 Članci 23. do 26. Zakona o pučkom pravobranitelju. Postupanje pučkoga pravobranitelja po pritužbama pravilo je i u drugim europskim državama. Tako je postupanje po pritužbama temeljni način iniciranja rada ove institucije u Švedskoj, Finskoj, Danskoj, Norveškoj, Ujedinjenom Kraljevstvu, Poljskoj i sl. O ovome vidi Aviani, op. cit., str. 126-141. 
preporukama, mišljenjima, prijedlozima i upozorenjima pučkog pravobranitelja te listu preporuka pučkog pravobranitelja za otklanjanje sustavnih nedostataka i nepravilnosti koje dovode do povreda ustavnih i zakonskih prava građana. $\mathrm{O}$ pojedinim pitanjima iz svog djelokruga on Hrvatskome saboru može podnositi i posebna izvješća, osobito ako se radi o ugroženosti ustavnih i zakonskih prava većeg stupnja ili značaja. Štoviše, kad u praćenju stanja u okviru svog djelokruga rada to ocijeni potrebnim, Hrvatskome saboru može ukazati i na potrebu donošenja i izmjene zakona i drugih propisa, odnosno može upozoriti na potrebu usklađivanja zakonskih i podzakonskih propisa s međunarodnim standardima i Ustavom Republike Hrvatske, kao što može ukazati Vladi Republike Hrvatske na potrebu donošenja zakona, podzakonskih propisa, strategija, programa te drugih akata iz područja zaštite ljudskih prava i sloboda te osiguranja vladavine prava. ${ }^{104}$

Ovim svojim ovlastima, koje ne uključuju niti objektivno stavljanje izvan snage niti meritorno rješavanje, već samo konstatiranje nastale nezakonitosti, pučki pravobranitelj svrstava se u subjekte nadzora koji zakonitosti u društvu doprinose više svojim autoritetom negoli izravnim nadzornim ovlastima. Njegova učinkovitost više ovisi o ugledu njegova položaja u pravnom sustavu i osobnoga autoriteta negoli o prirodi uglavnom neformalnih ovlasti koje posjeduje. Pučki pravobranitelj pokazuje se izuzetno korisnim institutom nadzora nad upravnim tijelima uopće, pa tako i nad izvršnim i upravnim tijelima jedinica lokalne samouprave, kada drugi mehanizmi pravne zaštite nisu podobni odnosno dostupni za otklanjanje utvrđenih nepravilnosti ili zloupotreba. ${ }^{105}$

\section{ZAKLJUČAK}

Državni nadzor nad lokalnom samoupravom označava posebnu vrstu nadzora nad upravom. Specifičnost tog nadzora leži u opreci između upravnih obilježja lokalne jedinice, što je čini pravnom osobom javnog prava, i njezinih samoupravnih obilježja, što je u odnosu na državu čini pravnom osobom privatnog prava. Međutim, koliko god bili u opreci, lokalna samouprava i državni nadzor nad njome neodvojivi su jedan od drugoga. Temeljni razlog i opravdanje uspostavljanja nadzora nad lokalnom samoupravom jest očuvanje ravnoteže između općeg javnog interesa, interesa lokalne zajednice i pojedinačnih prava. U tom smislu, država mora osigurati jedinstvenost pravnog poretka u državi, a istodobno uvažavati autonomiju lokalnih jedinica. Suprotnost između tih dvaju interesa predstavlja osnovu za određivanje granica nadzora državne nad lokalnom samoupravom: nadzorom je dopušteno zadirati u lokalnu autonomiju samo toliko koliko je potrebno radi očuvanja jedinstvenosti pravnog poretka.

Osnovna obilježja sustava lokalne samouprave u Hrvatskoj koja utječu na organizaciju sustava nadzora njezina rada jesu velik broj lokalnih jedinica s vrlo različitim kapacitetima te relativno širok djelokrug koji obuhvaća samoupravne

104 Članci 20. i 21. Zakona o pučkom pravobranitelju.

105 Tomić, Opšte ..., op. cit., str. 57-58. 
i povjerene poslove. Nedovoljni financijski i ljudski kapaciteti ograničavaju dio jedinica lokalne samouprave da učinkovito obavljaju zadaće koje su im zakonom povjerene te povećavaju rizik i opasnost ugrožavanja ili povrede načela ustavnosti i zakonitosti na kojima počiva pravni poredak u državi. Stoga je potrebno posebnu pozornost obratiti na zakonitost i pravilnost rada izvršnih i upravnih tijela lokalnih jedinica. Pritom se posebno važnima smatraju nadzor koji se obavlja unutar samih tijela lokalne samouprave, nadzor koji nad lokalnom samoupravom obavljaju tijela jedinice područne (regionalne) samouprave i državna upravna tijela, nadzor koji nad lokalnom samoupravom obavljaju sudovi te nadzor koji nad lokalnom samoupravom obavlja pučki pravobranitelj.

Mogućnost ispravljanja nezakonitosti i nepravilnosti unutar tijela lokalne samouprave pridonosi učinkovitosti i ekonomičnosti sustava javne uprave u cjelini. Stoga su razvijeni odgovarajući mehanizmi nadzora što ga mogu inicirati vanjski dionici, ali i sama javnopravna tijela: mogućnost podnošenja prigovora čelniku, hijerarhijski sustav odgovornosti službenika, uključujući njihovo ocjenjivanje i stegovnu odgovornost za povrede službene dužnosti, kao i utvrđivanje pravila etičkog ponašanja. Ti mehanizmi imaju cilj ispraviti nezakonito ili nepravilno postupanje te spriječiti njihovo ponavljanje u budućnosti.

Upravni nadzor nad lokalnom samoupravom provode hijerarhijski viša samoupravna tijela - županijska upravna tijela i nadležna tijela državne uprave. Hijerarhijski nadzor županijskih upravnih tijela posebno do izražaja dolazi u rješavanju upravih stvari u žalbenom postupku u kojem ona mogu žalbu odbiti ili je usvojiti i rješenje poništiti, pri čemu koriste samo kasacijske ovlasti, ili ga izmijeniti, u kojem slučaju koriste ovlast meritornoga odlučivanja. Posebnu važnost za nadzor nad tijelima jedinica lokalne samouprave imaju upravni i inspekcijski nadzor koji obavlja Ministarstvo uprave kao resorno središnje tijelo državne uprave nadležno za ovo upravno područje. Ovlasti kojima pritom raspolaže Ministarstvo u bitnome se svode na konstataciju nezakonitosti te na davanje preporuka i uputa nadziranim tijelima o načinu njezina ispravljanja i ne uključuju ni objektivno stavljanje izvan snage niti meritorno rješavanje. Može se zaključiti da je upravni nadzor nad izvršnim i upravnim tijelima lokalne samouprave načelno ustrojen na način da se njegovom provedbom poštuju samoupravne ovlasti lokalne samouprave i istodobno štiti zakonitost u cjelokupnom pravnom sustavu. Međutim, učinkovitost i djelotvornost njegove provedbe u praksi su vrlo ograničene zbog velikog broja subjekata koje treba nadzirati i nedovoljnih kapaciteta nadležnih nadzornih službi.

Izuzetno važnu komponentu nadzora nad radom tijela lokalne samouprave čini sudska zaštita osigurana upravnim sporom. Ona treba zajamčiti pravilnu provedbu pravnih propisa kada tijelo jedinice područne (regionalne) samouprave u žalbenom postupku meritorno rješava o upravnoj stari o kojoj je u prvom stupnju odlučivalo upravno tijelo jedinice lokalne samouprave, ali i kada središnja državna vlast provodi bilo kakav oblik upravnoga nadzora nad pojedinačnim odlukama i postupanjima lokalne samouprave. Valja naglasiti kako je nadzor koji se provodi u upravnom sporu samo jedan od segmenata sudskoga nadzora 
nad radom javne uprave jer, primjerice, županijski i općinski sudovi imaju važnu ulogu u utvrđivanju kaznene odgovornosti ovih osoba ili odlučivanja o iznosu naknade štete nanesene pojedincima nezakonitim radom službenika zaposlenih $\mathrm{u}$ ovim tijelima.

Konačno, stanovit oblik nadzora nad izvršnim i upravnim tijelima jedinica lokalne samouprave, iako s prilično slabim nadzornim ovlastima, obavlja pučki pravobranitelj. Njegove ovlasti ne uključuju objektivno stavljanje izvan snage niti meritorno rješavanje, već samo konstatiranje nastale nezakonitosti. On, međutim, svojim djelovanjem pridonosi poštovanju zakonitosti u društvu svojim autoritetom, a ne izravnim nadzornim ovlastima. Stoga učinkovitost tog nadzora više ovisi o ugledu njegova položaja u pravnom sustavu i osobnom autoritetu negoli o uglavnom neformalnim ovlastima kojima raspolaže. $U$ tom smislu, pučki pravobranitelj može biti izuzetno važan institut nadzora u okolnostima kada drugi mehanizmi pravne zaštite nisu pogodni ili dostupni za otklanjanje nepravilnosti ili zloupotreba.

Na kraju treba istaknuti da se od početnog ustroja sustava lokalne samouprave u Hrvatskoj kontinuirano raspravlja o njegovoj racionalnosti i učinkovitosti te se najavljuju promjene funkcionalnog i ustrojstvenog reformskog opsega. Upravo u određivanju smjera ovih promjena dosadašnji rezultati nadzora nad upravom trebali bi biti važan smjerokaz daljnjeg preustroja. Naime, nadzor ne bi trebao imati jedino zadaću ispravljanja konkretnih nezakonitosti i nepravilnosti te generalne prevencije već je on po svojoj naravi aktivnost koja ukazuje na slabosti u sustavu te upućuje u kojem smjeru treba djelovati s ciljem njegova unapređenja i razvitka. Stoga je u postupku reforme sustava lokalne samouprave nužno koristiti upravo ovu funkciju nadzora.

Zaključno se može ustvrditi da sustav nadzora nad lokalnom samoupravom u Hrvatskoj treba još razvijati i pritom mu treba dati veće značenje i širu ulogu od one koju ima danas. U procesu reforme hrvatske uprave u cjelini i njezina ustrojavanja na načelima učinkovitosti i dobrog upravljanja bit će nužno ozbiljnije pozabaviti se ovim pitanjem.

\section{Pravni izvori}

1.Etički kodeks službenika i namještenika Grada Koprivnice, Glasnik Grada Koprivnice, br. 1/15.

2.Etički kodeks službenika i namještenika upravnih tijela Grada Rijeke, Službene novine Primorsko-goranske županije, br. 54/12.

3.Uredba o unutarnjem ustrojstvu Ministarstva uprave, Narodne novine, br. 28/12.

4.Ustav Republike Hrvatske, Narodne novine, br. 56/90., 135/97., 113/00., 28/01., 76/10. i 5/14.

5.World-wide Declaration of Local Self-government, Iula, 2003., dostupno na: www. bunken.nga.gr.jp/siryousitu/eturansitu/charter/iula_decl_txt.html. 
Dr. sc. Dario Đerđa i dr. sc. Teodor Antić: Nadzor nad radom izvršnih i upravnih tijela jedinica... Zbornik radova Pravnog fakulteta u Splitu, god. 53, 1/2016., str. 165.-205.

6.Zakon o potvrđivanju Europske povelje o lokalnoj samoupravi, Narodne novine međunarodni ugovori, broj 14/97., 2/07., 4/08. i 5/08.

7.Zakon o elektroničkim komunikacijama, Narodne novine, br. 73/08., 90/11., 133/12. i $80 / 13$.

8.Zakon o financiranju jedinica lokalne i područne (regionalne) samouprave, Narodne novine, br. 117/93., 92/94., 69/97., 33/00., 73/00., 127/00., 59/01., 107/01., 117/01., 150/02., 147/03., 132/06., 26/07., 73/08., 25/12. i 147/14.

9.Zakon o Gradu Zagrebu, Narodne novine, br. 62/01., 125/08., 36/09. i 119/14.

10. Zakon o komunalnom gospodarstvu, Narodne novine, br. 36/95., 36/95., 70/97., 128/99., 57/00., 129/00., 59/01., 82/04., 178/04., 38/09., 79/09., 153/09., 49/11., 84/11., 90/11., 144/12., 94/13., 153/13., 147/14. i 36/15.

11. Zakon o lokalnim izborima, Narodne novine, br. 144/12.

12. Zakon o lokalnoj i područnoj (regionalnoj) samoupravi, Narodne novine, br. 3/01., 60/01., 129/05., 109/07., 125/08., 36/09., 150/11. i 144/12.

13. Zakon o općem upravnom postupku, Narodne novine, br. 47/09.

14. Zakonom o osiguranju kvalitete u znanosti i visokom obrazovanju, Narodne novine, br. $45 / 09$.

15. Zakon o područjima županija, gradova i općina u Republici Hrvatskoj, Narodne novine, br. 86/06., 125/06., 16/07., 95/08., 46/10., 145/10., 37/13., 44/13. i 45/13.

16. Zakon o pravu na pristup informacijama, Narodne novine, br. 25/13.

17. Zakon o predškolskom odgoju i obrazovanju, Narodne novine, br. 10/97., 107/07. i $94 / 13$.

18. Zakon o pučkom pravobranitelju, Narodne novine, br. 76/12.

19. Zakon o službenicima i namještenicima u lokalnoj i područnoj (regionalnoj) samoupravi, Narodne novine, br. 86/08. i 61/11.

20. Zakon o socijalnoj skrbi, Narodne novine, br. 157/13. i 152/14.

21. Zakon o sustavu državne uprave, Narodne novine, br. 150/11. i 12/13.

22. Zakon o upravnim sporovima, Narodne novine, br. 20/10., 143/12. i 152/14.

23. Zakon o upravnoj inspekciji, Narodne novine, br. 63/08.

24. Zakona o ustanovama, Narodne novine, br. 76/93., 29/97., 47/99. i 35/08.

25. Zakon o ustrojstvu i djelokrugu ministarstva i drugih središnjih tijela državne uprave, Narodne novine, br. 150/11., 22/12., 39/13., 125/13. i 148/13.

26. Zakon o vatrogastvu, Narodne novine, br. 106/99., 117/01., 36/02., 96/03., 174/04., 38/09. i 80/10.

\section{Literatura}

1. Antić, Teodor, „Nadzor i pravna zaštita lokalne samouprave - de lege lata i de lege ferenda", Nova hrvatska lokalna i regionalna samouprava, Hrvatska akademija znanosti i umjetnosti, Zagreb, 2010. 
Dr. sc. Dario Đerđa i dr. sc. Teodor Antić: Nadzor nad radom izvršnih i upravnih tijela jedinica... Zbornik radova Pravnog fakulteta u Splitu, god. 53, 1/2016., str. 165.-205.

2. Antić, Teodor, „Nadzor lokalne samouprave - postojeće stanje i prijedlog promjena“, Reforma lokalne i regionalne samouprave u Republici Hrvatskoj, Institut za javnu upravu, Pravni fakultet Sveučilišta u Zagrebu, Zagreb, 2013.

3. Aviani, Damir, Parlamentarni ombudsman, Pravni fakultet u Splitu, Split, 1999.

4. Becker, Erich, „Die Selbstverwaltung als verfassungsrechtliche Grundlage der kommunalen Ordnung in Bund und Ländern“, Handbuch der kommunalen Wissenschaft und Praxis, Springer-Verlag, Berlin, Göttingen, Heidelberg, 1956.

5. Blažević, Robert, Upravna znanost, Pravni fakultet u Rijeci, Rijeka, 2015.

6. Borković, Ivo, „Kontrola uprave putem redovitih sudova“, Hrestomatija upravnog prava, Društveno veleučilište u Zagrebu, Pravni fakultet u Zagrebu, Zagreb, 2003.

7. Borković, Ivo, Upravno pravo, Narodne novine, Zagreb, 2002.

8. Bouvier, Jacques, „Local government in Belgium“, Local government in the Member States of the European Union: a comparative legal perspective, National institute for public administration, Madrid, 2012.

9. Braibant, Guy, „Administrativno pravo Francuske“, Službeni list Jugoslavije, Beograd, 2002.

10. Cardona, Francisco, „Converging Judicial Control of the Administration in Europe", Judicial Reform and Administrative Justice, SIGMA, 2005.

11. Đerđa, Dario, Opći upravni postupak u Republici Hrvatskoj, Inženjerski biro, Zagreb, 2010.

12. Đerđa, Dario, „Upravni spor u Hrvatskoj: sadašnje stanje i pravci reforme“, Zbornik Pravnog fakulteta Sveučilišta u Rijeci, vol. 29., br. 1., 2008.

13. Gagro, Božidar, „Upravnosudski nadzor zakonitosti akata jedinica lokalne i područne (regionalne) samouprave“, Hrvatska javna uprava, god. 3., br. 3-4., 2001.

14. Gamper, Anna, „Local Government in Austria“, Local government in the Member States of the European Union: a comparative legal perspective, National institute for public administration, Madrid, 2012.

15. Gatarić, Đuro, Transformacija državne uprave, Pravni fakultet u Zagrebu, Zagreb - Čakovec, 1984.

16. Godišnje izvješće o radu Ministarstva uprave za 2012. godinu, dostupno na: https://uprava.gov.hr/pristup- informacijama/strategije-planovi-i-izvješća/izvješća/1055

17. Godišnje izvješće o radu Ministarstva uprave za 2013. godinu, dostupno na: https://uprava.gov.hr/pristup- informacijama/strategije-planovi-i-izvješća/izvješća/1055

18. Godišnje izvješće o radu Ministarstva uprave za 2014. godinu, dostupno na: https://uprava.gov.hr/pristup- informacijama/strategije-planovi-i-izvješća/izvješća/1055

19. Grafenauer, Božo, Lokalna samouprava na Slovenskem - teritorijalnoorganizacijske strukture, Univerza v Mariboru, Pravna fakulteta v Mariboru, Maribor, 2000

20. Greve, Emil, „Local government in Denmark“, Local government in the Member States of the European Union: a comparative legal perspective, National institute for public administration, Madrid, 2012. 
Dr. sc. Dario Đerđa i dr. sc. Teodor Antić: Nadzor nad radom izvršnih i upravnih tijela jedinica... Zbornik radova Pravnog fakulteta u Splitu, god. 53, 1/2016., str. 165.-205.

21. Hertzog, Robert, „Local government in France“, Local government in the Member States of the European Union: a comparative legal perspective, National institute for public administration, Madrid, 2012.

22. Hlepans, Nikolaos-Komninos, „Local government in Greece“, Local government in the Member States of the European Union: a comparative legal perspective, National institute for public administration, Madrid, 2012.

23. Ivančević, Velimir, „Pravna zaštita građana kod šutnje administracije“, Hrestomatija upravnog prava, Društveno veleučilište u Zagrebu, Pravni fakultet u Zagrebu, Zagreb, 2003.

24. Kadečka, Stanislav, „Local government in Czech Republic“, Local government in the Member States of the European Union: a comparative legal perspective, National institute for public administration, Madrid, 2012.

25. Kasabašić, Štefanija, „Državni nadzor i zaštita lokalne i područne (regionalne) samouprave“, Informator, god. 54., br. 5435., 2006.

26. Kontingenti stanovništva po gradovima/općinama, popis 2001., Državni zavod za statistiku, dostupno na:

www.dzs.hr/Hrv/censuses/census2001/Popis/H01_01_02/H01_01_02.html

27. Kontingenti stanovništva po gradovima/općinama, popis 2011., Državni zavod za statistiku, dostupno na: html,

www.dzs.hr/Hrv/censuses/census2011/results/htm/H01_01_03/H01_01_03_zup01.

28. Koprić, Ivan, ,Karakteristike sustava lokalne samouprave u Hrvatskoj“, Hrvatska javna uprava, god. 10., br. 2., 2010.

29. Koprić, Ivan, „Proširenje lokalnog samoupravnog djelokruga i sužavanje nadzora središnjih državnih organa“, Hrvatska javna uprava, god. 2., br. 3, 2000.

30. Krbek, Ivo, „Državni nadzor nad samoupravom“, Mjesečnik: glasilo pravničkog društva, god. 65., br. 7-8. 1939.

31. Krbek, Ivo, Osnovi upravnog prava FNRJ, Jugoslavenska akademija znanosti i umjetnosti, Zagreb, 1950.

32. Krbek, Ivo, Pravo jugoslavenske javne uprave: Osnovna pitanja i prava građana, knj. 1., Birotehnički izdavački zavod, Zagreb, 1960.

33. Krijan, Pero, Komentar Zakona o općem upravnom postupku, Novi informator, Zagreb, 2004., str. 321.

34. Krijan, Pero, ,Javne ovlasti kao poseban oblik javne vlasti“, Informator, god. 54. br. 5461-5462, 2006.

35. Krišković, Velimir, „Viši nadzor nad upravom“, Hrestomatija upravnog prava, Društveno veleučilište u Zagrebu, Pravni fakultet u Zagrebu, Zagreb, 2003.

36. Kujundžić, Ivica, „Upravno sudstvo u Hrvatskoj i zemljama Europske unije“, Upravno pravo i upravni postupak u praksi - aktualna pitanja i problemi, Inženjerski biro, Zagreb, 2006.

37. Kulesza, Michal, Szescilo, Dawid, „Local government in Poland“, Local government in the Member States of the European Union: a comparative legal perspective, National institute for public administration, Madrid, 2012. 
Dr. sc. Dario Đerđa i dr. sc. Teodor Antić: Nadzor nad radom izvršnih i upravnih tijela jedinica... Zbornik radova Pravnog fakulteta u Splitu, god. 53, 1/2016., str. 165.-205.

38. Local self-government in the Member States of the European Union: a comparative legal perspective, National Institute of Public Administration, Spain, Madrid, 2012.

39. Mäenpää, Olli, „Local government in Finland“, Local government in the Member States of the European Union: a comparative legal perspective, National institute for public administration, Madrid, 2012.

40. Medvedović, Dragan, „Kakva pravna zaštita građana od nezakonitih i nepravilnih upravnih akata lokalnih organa“, Hrestomatija upravnog prava, Društveno veleučilište u Zagrebu, Pravni fakultet u Zagrebu, Zagreb, 2003.

41. Medvedović, Dragan, „Kontrola ustavnosti i zakonitosti općih akata općina i gradova“, Hrvatska javna uprava, god. 3., br. 3-4., 2001.

42. Medvedović, Dragan, „Nadzor izvršne vlasti nad općim aktima jedinica lokalne samouprave - de lege lata i de lege ferenda“, Hrvatska javna uprava, god. 5., br. 1., 2005.

43. Pusić, Eugen, „Kontrola vlasti pomoću vlasti“, Politička misao, vol. 31., br. 3., 1994.

44. Pusić, Eugen, Nauka o upravi, Školska knjiga, Zagreb, 2002.

45. Pusić, Eugen, „Tko da čuva čuvare“, Erasmus, br. 10., 1995.

46. Rajko, Alen, „Javnopravna tijela prema novom Zakonu o upravnim sporovima“, Hrvatska pravna revija, god. 12., br. 1., 2012.

47. Rems, Vladimir, „Inspekcijski nadzor nad tijelima javne vlasti te nad fizičkim i pravnim osobama u zakonodavstvu Republike Hrvatske“, Hrvatska pravna revija, god. 8., br. 2., 2008.

48. Schefold, Dian, „Local government in Germany“, Local government in the Member States of the European Union: a comparative legal perspective, National institute for public administration, Madrid, 2012.

49. Szente, Zoltan, „Local government in Hungary“, Local government in Lithuania, Local government in the Member States of the European Union: a comparative legal perspective, National institute for public administration, Madrid, 2012.

50. Šaparniene, Diana, Lazauskiene, Aiste, „Local government in Lithuania“, Local government in the Member States of the European Union: a comparative legal perspective, National institute for public administration, Madrid, 2012.

51. Šprajc, Ivan, „Nadzor nad djelovanjem tijela jedinica lokalne samouprave: međunarodnopravne osnove i pregled usporednog prava“, Hrvatska javna uprava, god. 2., br. 3., 2000.

52. Tomić, Zoran R., “Upravno pravo - sistem”, Službeni list SFRJ, Beograd, 2002.

53. Tomić, Zoran R., Opšte upravno pravo, Pravni fakultet u Beogradu, Beograd, 2009

54. Tropina-Godec, Željka, „Još o nadzoru općih akata i zakonitosti rada predstavničkih tijela jedinica lokalne i područne (regionalne) samouprave“, Informator, god. 54., br. 5439, 2006.

55. Vandelli, Luciano, „Local government in Italy“, Local government in the Member States of the European Union: a comparative legal perspective, National institute for public administration, Madrid, 2012. 
Dr. sc. Dario Đerđa i dr. sc. Teodor Antić: Nadzor nad radom izvršnih i upravnih tijela jedinica... Zbornik radova Pravnog fakulteta u Splitu, god. 53, 1/2016., str. 165.-205.

56. Van Haaren-Dresens, Ine, „Local government in Netherlands“, Local government in the Member States of the European Union: a comparative legal perspective, National institute for public administration, Madrid, 2012.,

57. Vilka, Inga, „Local government in Latvia“, Local government in the Member States of the European Union: a comparative legal perspective, National institute for public administration, Madrid, 2012.

\section{SUPERVISION OF THE WORK OF EXECUTIVE AND ADMINISTRATIVE BODIES OF UNITS OF LOCAL SELF GOVERNMENT IN CROATIA}

The specificity of supervision over the work of executive and administrative bodies of local self-government lies in the contradiction between administrative characteristics of units of local self-government and its self-administrative characteristics. Therefore, it should be organised in a way that respects the self-administration powers of local self-government, but at the same time, protects legality in the entire legal system. This paper investigates the supervision of executive and administrative bodies of units of local self-government in Croatia. Here, after considering the nature of the supervision, subjects of supervision and supervisory powers, in particular the forms of supervision are analysed over executive and administrative bodies of units of local self-government, hierarchical administrative supervision by bodies of regional self-government and administrative and inspectorial supervision by the Ministry of Administration, administrative court supervision as well as supervision by the ombudsman. Particular emphasis is placed on the instruments for implementation of every individual supervision and on the supervisory powers at the disposal of supervisory bodies. Thereby attention is given to the influence on the efficiency and effectiveness of supervision, the number and size of local units and consequently their objective capability to carry out duties within the sphere of self-government.

Key words: supervision of public administration, local self-government, supervision of local executive and administrative bodies 